\title{
Cytogeography and morphological characterisation of a taxonomic, polyploid complex of Mimosa (Leguminosae) from subtropical South America
}

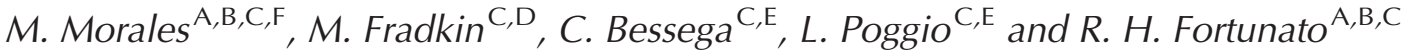 \\ Anstituto de Recursos Biológicos (CIRN, CNIA), Instituto Nacional de Investigaciones Agropecuarias (INTA), \\ Nicolás Repetto \& Los Reseros s.n. (1686), Hurlingham, Buenos Aires, Argentina. \\ ${ }^{B}$ Facultad de Agronomía y Ciencias Agroalimentarias, Universidad de Morón, Cabildo 134, (1408), Morón, \\ Buenos Aires, Argentina. \\ ${ }^{C}$ Consejo Nacional de Investigaciones Científicas y Técnicas (CONICET), Godoy Cruz 2900, (C1425FQB), \\ Ciudad Autónoma de Buenos Aires, Argentina. \\ ${ }^{D}$ Cátedra de Mejoramiento Genético, Facultad de Ciencias Agrarias, Universidad Nacional de Lomas \\ de Zamora (UNLZ), Camino de Cintura \& Juan XXIII, (1836), Lavallol, Buenos Aires, Argentina. \\ ${ }^{E}$ Facultad de Ciencias Exactas y Naturales, Universidad de Buenos Aires (UBA), Intendente Güiraldes 2160 \\ (C1428EGA), Ciudad Autónoma de Buenos Aires, Argentina. \\ FCorresponding author. Email: mmorales0007@gmail.com; morales.matias@inta.gob.ar
}

\begin{abstract}
Mimosa subseries Dolentes Barneby and Brevipedes Barneby are ecologically and morphologically highdiversified infrageneric taxa of this genus in southern South America. We performed a cytogenetical and morphological analysis of both subseries. Chromosome numbers from accessions throughout the area of distribution were studied. The chromosome numbers $2 n=8 x=104$ for $M$. dolens subsp. callosa (Benth.) Barneby, M. dolens subsp. acerba varieties acerba (Benth.) Barneby, latifolia (Benth.) Barneby and rudis (Benth.) Barneby, M. dolens subsp. rigida var. rigescens (Benth.) Barneby, var. anisitsii (Lindm.) Barneby and var. foliolosa (Benth.) Barneby; and $2 n=4 x=52$ for $M$. sceptrum Barneby, $M$. aff. custodis Barneby and $M$. dolens var. pangloea Barneby are presented for the first time. Their karyotypes were symmetric, with small chromosomes. There were several areas with taxa growing in sympatry, occasionally with intermediate forms. No diploids were found, which suggests the presence of either a declining polyploid complex or ancient polyploidy in the clade of southernmost representatives of $M$. series Mimosa, the most derived of the genus. Some vegetative, inflorescence and carpological characters seem to be associated with chromosome duplication. The distribution pattern of the cytotypes suggests events of chromosome duplication in centres of diversity and expansion of octoploids to the southernmost areas of distribution. Our findings support the importance of polyploidy in the morphological diversity, distribution and speciation of this complex.
\end{abstract}

Additional keywords: hybrid zones, octoploid, plant speciation.

Received 17 August 2016, accepted 18 January 2018, published online 7 May 2018

\section{Introduction}

The genus Mimosa L. is composed of more than 530 species and it is one of the most diversified genera in the family Leguminosae (Bessega and Fortunato 2011; Simon et al.2011). Mimosa is more abundant in the Neotropics, where $\sim 90 \%$ of the species occur. This genus has the following two centres of diversification: (1) South America, including Amazonas Basin and adjacent regions of Brazil, Argentina, Paraguay and Uruguay; and (2) Mesoamerica and southern Mexico. Other minor centres of diversification include Cuba, La Hispaniola, Orinoco Basin and Madagascar (Barneby 1991; Morales and Fortunato 2016).
This megadiverse genus was studied extensively by Bentham (1841, 1842, 1875, 1876), who proposed the following two sections: Habbasia DC. and Mimosa, on the basis of the number of stamens, namely, haplostemonous $v$. diplostemonous flowers respectively. Later, Barneby (1991) revised the Neotropical species and proposed five sections. Mimosa section Mimosa was considered by this author the most evolved and diversified; he also divided it into three series, Mimosa, Myriophyllae Benth. and Modestae Benth. Mimosa series Mimosa is the most diversified among them, including 37 subseries and $\sim 159$ species (Barneby 1991). 
In Mimosa, it was postulated that the basic chromosome number is $x=13$ (Goldblatt 1981; Isely 1971). This basic chromosome number is predominant in tribes Acacieae, Ingeae and Mimoseae, and it was apparently derived via disploidy from $x=14$, which is the basic chromosome number of the genus Dinizia Ducke (Poggio et al. 2008), an early divergent genus of the 'Mimosoideae' clade (Lewis et al. 2005; Azani et al. 2017). Some genera of Mimoseae have $x=14$, such as, for example, Prosopis L. and Neptunia Lour. (Lewis et al. 2005; Poggio et al. 2008). Successive and extensive cytological studies performed on representatives from the Paleotropics (Bir and Kumari 1975; Nazeer and Madhusoodanan 1983) and Neotropics (Seijo 1993, 1999, 2000; Seijo and Fernández 2001; Morales et al. 2010, 2011, 2012, 2014a, 2014b, 2015; Dahmer et al. 2011) support $x=13$ as the basic chromosome number of the genus. In these works, several ploidy levels were postulated, including $2 x=26$, $3 x=39,4 x=52,6 x=78$ and $8 x=104$.

The most derived infrageneric groups are polyploid or exhibit different ploidy levels, suggesting that polyploidy is an important evolutionary force that can lead to speciation (Seijo and Fernández 2001; Morales et al. 2010, 2014a, 2014b; Dahmer et al. 2011). Presence of polyploids of different origin has been hypothesised on the basis of morphological data (Morales et al. 2010, 2014a, 2014b).

Polyploidy in Mimosa has been frequently associated with taxonomic complexes that have high morphological variation and are, therefore, difficult to circumscribe, and this has been interpreted as indicating that polyploids are of hybrid origin (Morales et al. 2010, 2014a, 2014b). Polyploidy seems to be a decisive phenomenon in the diversification of the genus, especially in the southern area of distribution in America, where polyploids are especially concentrated (Seijo 1999; Seijo and Fernández 2001; Morales et al. 2010, 2014a; Dahmer et al. 2011).

The section Mimosa series Mimosa subseries Dolentes Barneby and Brevipedes Barneby comprise subshrubs from subtropical grasslands of Brazil, Argentina, Paraguay and Uruguay, with conjugate pinnae and exerted inflorescences (Barneby 1991, pp. 578-581, 705-706). Both subseries appear to be close morphologically (Barneby 1991, p. 706; Morales 2011). Subseries Dolentes includes the species of Mimosa with virgate erect stems, mostly one-jugate pinnae, determinate (cymose) inflorescences, fertile haplostemonous flowers and pods with valvate dehiscence grouped in spheroid clusters. Subseries Brevipedes includes subshrubs with one-jugate pinnae, indeterminate (racemose) inflorescences, haplostemonous fertile flowers, and either clustered pods (i.e. fruit with only valvate dehiscence, i.e. valves separating entire from replum) or unclustered typical craspedia (i.e. fruit breaking up into freefalling articles) (Barneby 1991, pp. 705-706).

Mimosa subseries Dolentes is monospecific, with $M$. dolens Vell., divided in five subspecies and eleven varieties, including M. dolens subsp. dolens var. dolens, M. dolens var. pangloea Barneby; M. dolens subsp. eriophylla (Benth.) Barneby; M. dolens subsp. callosa (Benth.) Barneby; M. dolens subsp. acerba (Benth.) Barneby var. acerba, M. dolens subsp. acerba var. latifolia (Benth.) Barneby, M. dolens subsp. acerba var. rudis (Benth.) Barneby and M. dolens subsp. acerba var. pseudorigida (Benth.) Barneby; M. dolens subsp. rigida (Benth.) Barneby var. rigida, M. dolens subsp. rigida var. rigescens (Benth.)
Barneby, M. dolens subsp. rigida var. deterior Barneby and M. dolens subsp. rigida var. foliolosa (Benth.) Barneby (Barneby 1991, p. 581). Subseries Brevipedes comprises nine species, including M. brevipes Benth., M. longiracemosa (Burkart) Barneby, M. fernandez-casasii Barneby \& Fortunato, M. sceptrum Barneby, M. custodis Barneby, M. diversipila M.Micheli, M. pseudopetiolaris Barneby, M. cryptogloea Barneby and M. nitidula Barneby. Mimosa sceptrum, M. custodis and $M$. longiracemosa have pods with valvate dehiscence grouped in relatively dense spheroid clusters (Burkart 1948, pp. 192-196; Barneby 1991, pp. 706-707 ; Morales 2011); the remainder of species have craspedia not grouped in spheroid clusters, with the exception of $M$. nitidula and $M$. cryptogloea, whose fruit have not been studied because specimens in herbaria are lacking these organs (Barneby 1991, pp. 711-712, 714-715; Morales 2011). Mimosa sceptrum and M. custodis have intermediate morphology between the subseries Dolentes and Brevipedes and their taxonomic position and circumscription are currently in question (Morales 2011).

These subseries have high morphological and ecological diversity. Although the subseries Dolentes is monotypic according to Barneby (1991, pp. 578-580), the majority of its infraspecific taxa, subspecies and varieties, were previously considered to be species (Bentham 1842, 1846). Some characters used to distinguish infraspecific taxa in subseries Dolentes and Brevipedes have also been used to distinguish species in other series or subseries of the section Mimosa (Barneby 1991, pp. 506-515, 533-537).

Although subseries Dolentes and Brevipedes comprise only few species, their infraspecific morphological variability is remarkable and there is some difficulty in adequately distinguishing their taxa. These groups are widely distributed in different ecosystems of subtropical and warm-temperate South America (Barneby 1991, pp. 581, 706).

In the present study, we compared the chromosome number and karyotype of representatives of subseries Dolentes and Brevipedes with morphological variability, so as to generate hypotheses about the evolution of their composite species; we also provide a model for their future taxonomic revision.

\section{Materials and methods}

\section{Plant material}

Specimens and material for cytogenetic studies were collected during different field trips in Argentina (2006), Paraguay (2005 and 2008) and Brazil (2009), in expeditions with colleagues from these countries (Table 1). The specimens were deposited in BAB, CTES, FCQ, HUCS, MBM and SI. They were identified according to Barneby (1991) and later nomenclatural modifications (Fortunato et al. 2008; Azani et al. 2017), and compared with the nomenclatural types of the taxa.

\section{Chromosome studies}

For each accession, chromosomes of 3-10 individuals were studied. The seeds collected during the field trips were germinated in Petri dishes at $25^{\circ} \mathrm{C}$. Roots with $\sim 1-\mathrm{cm}$ length were pretreated with $0.0002 \mathrm{M} 8$-hydroxyquinoline for 4-7 h and fixed with $3: 1$ ethanol : glacial acetic acid solution. The material was preserved at $5^{\circ} \mathrm{C}$ until its use. 
Table 1. Voucher specimens and chromosome numbers of members of Mimosa subseries Dolentes and Brevipedes complex

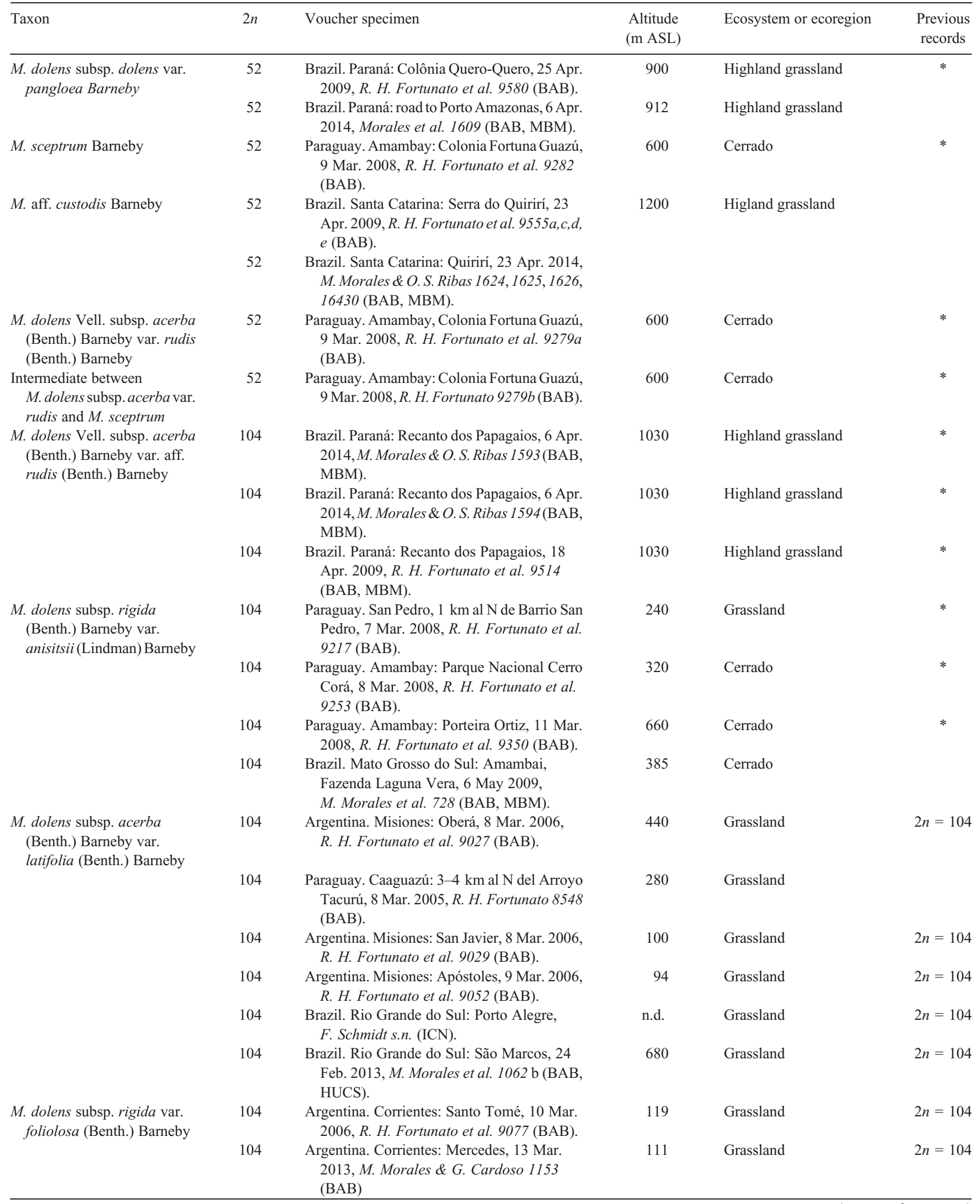


Table 1. (continued)

\begin{tabular}{|c|c|c|c|c|c|}
\hline Taxon & $2 n$ & Voucher specimen & $\begin{array}{l}\text { Altitude } \\
\text { (m ASL) }\end{array}$ & Ecosystem or ecoregion & $\begin{array}{c}\text { Previous } \\
\text { records }\end{array}$ \\
\hline & 104 & $\begin{array}{l}\text { Paraguay. Amambay: Porteira Ortiz, } 11 \text { Mar. } \\
\text { 2008, R. H. Fortunato et al. } 9347 \text { (BAB). }\end{array}$ & 660 & Cerrado & $2 n=104$ \\
\hline & 104 & $\begin{array}{l}\text { Brazil. Mato Grosso do Sul: Alrededores de } \\
\text { Bella Vista, } 9 \text { May 2009, M. Morales et al. } \\
819 \text { (BAB). }\end{array}$ & 200 & Cerrado & $2 n=104$ \\
\hline & 104 & $\begin{array}{l}\text { Brazil. Rio Grande do Sul: São Marcos, } 24 \\
\text { Feb. 2013, M. Morales et al. } 1062 \text { g (BAB, } \\
\text { HUCS). }\end{array}$ & 680 & Grassland & $2 n=104$ \\
\hline $\begin{array}{l}\text { M. dolens subsp. callosa } \\
\text { (Benth.) Barneby }\end{array}$ & 104 & $\begin{array}{l}\text { Paraguay. Amambay: Porteira Ortiz, } 11 \text { Mar. } \\
\text { 2008, R. H. Fortunato et al. } 9347 \text { (BAB). }\end{array}$ & 660 & Cerrado & * \\
\hline \multirow[t]{2}{*}{$\begin{array}{l}\text { M. dolens subsp. acerba var. } \\
\quad \text { acerba }\end{array}$} & 104 & $\begin{array}{l}\text { Brazil. Paraná: Recanto Botuquara, May } 2009 \text {, } \\
\text { O. S. Ribas et al. } 8218 \text { (BAB). }\end{array}$ & 1030 & Highland grassland & * \\
\hline & 104 & $\begin{array}{l}\text { Brazil. Paraná: Laranjeiras do Sul, BR277, } 20 \\
\text { Apr. 2009, R. H. Fortunato et al. } 9551 \\
\text { (BAB). }\end{array}$ & 950 & Highland grassland & * \\
\hline $\begin{array}{l}\text { Intermediate individuals } \\
\text { between } M \text {. dolens var. } \\
\text { acerba and } M \text {. dolens subsp. } \\
\text { rigida } \text { var. foliolosa }\end{array}$ & 104 & $\begin{array}{l}\text { Brazil. Paraná: Recanto dos Papagaios, } 18 \\
\text { Arp. 2009, R. H. Fortunato et al. } 9517 \\
\text { (BAB). }\end{array}$ & 1030 & Highland grassland & * \\
\hline
\end{tabular}

Fixed roots were washed in $0.01 \mathrm{M}$ citric acid-sodium citrate, $\mathrm{pH} 4.6$, buffer to remove the fixative, and transferred to an enzyme solution containing $2 \mathrm{~mL}$ of $2 \%$ cellulase $(\mathrm{w} / \mathrm{v})$ and $20 \%(\mathrm{v} / \mathrm{v})$ pectinase. The softened material was washed again in the buffer solution mentioned above. To analyse the chromosome number and chromosome size, the material was stained with a drop of haematoxylin or acetic carmine, and the chromosome slides were made by 'squash' technique (Egozcue 1971).

Chromosome length by haploid genome (CLHG) and chromosome area by haploid genome $(\mathrm{CAHG})$ were measured by the means Micromeasure (University of Colorado State, Fort Collins, CO, USA, ver. 3.3, Reeves 2001). CLHG and CAHG were calculated by dividing the total chromosome length and total chromosome area by the ploidy level. To study the distribution of both variables, a normality test of Shapiro-Wilks with modifications (Mahibbur Rahman and Govindarajulu 1997) was used. Homoscedasticity was analysed by means Levene's test (Levene 1960). ANOVA was used to compare the mean values of CLHG and CAHG between ploidy levels. Parametric one-way ANOVA was conducted when variables were normally distributed and homoscedastic, whereas a non-parametric Kruskall-Wallis test was conducted when variables were not normally distributed and heteroscedastic. Where variables exhibited statistically significant differences, a post hoc pairwise comparison (Tukey or Mann-Whiney test) was undertaken to identify group pairs involved.

The inter-chromosomal asymmetry index $\left(\mathrm{A}_{2}\right)$, which describes variation in chromosome length in a complement, was calculated on the basis of Romero Zarco (1986), as follows:

$$
\mathrm{A}_{2}=S X^{-1}
$$

where $S$ represents standard deviation and $X$ the mean of chromosome length.

\section{Morphological analysis of voucher specimens}

We scored 25 quantitative and qualitative vegetative, floral and carpological characters (Table 2) from voucher specimens of the subseries Dolentes and Brevipedes. Cluster analysis was conducted using PAST (Hammer et al. 2001). Some morphological characters, especially floral characters, were not included in the cluster analysis because they were absent from the majority of accessions. Cluster analysis was conducted using the following three algorithms: single linkage, unweighted pairgroup method with arithmetic mean (UPGMA), and Ward's method. Results from UPGMA had the highest cophenetic correlation (0.8425) and are presented here. We used mixed similarity measures, namely, Gower for continuous and ordinal variables, Hamming/p-distance for nominal variables and Jaccard for the binary variables.

Several univariate analyses were conducted in quantitative characters to detect significant differences between the following two groupings: (1) among groups visualised by the means of the UPGMA analysis; and (2) between ploidy levels. As for analysis of chromosomes, we checked the normality and homoscedasticity of variables to decide whether to use parametric or non-parametric tests. Normality and homocedasticity were evaluated by the means the modified Shapiro-Wilk's test (mentioned above) and Levene's test (Levene 1960) respectively.

We checked whether there were significant differences among groups from UPGMA analysis by using tests of ANOVA, either parametric or non-parametric (KruskallWallis test), depending on the properties (normal distribution and homoscedasticity) of each variable. Comparisons among groups were performed on variables in which statistically significant differences were found using parametric (Tukey) or non-parametric (Mann and Whitney 1947) post hoc pairwise tests (Appendix 1, Table A3). All these univariate analyses were performed with INFOSTAT (Di Rienzo et al. 2009) and PAST software. 
Table 2. Variables used in the morphological analysis of Mimosa subseries Dolentes and Brevipedes

\begin{tabular}{|c|c|}
\hline Type of variable & Variables \\
\hline Quantitative, discrete & Leaflet pairs per pinna; visible primary nerves per leaflet; heads per inflorescence axis; nodes per inflorescence axis. \\
\hline Qualitative, nominal & $\begin{array}{l}\text { Leaflet pubescence (strigose, glabrous, intermediate, glandular); leaflet secondary venation (brochidodrome, not visible, } \\
\text { anastomosed with pallid band, intermediate between them); leaflet margin (glandular, setose uniseriate, setose pluriseriate, } \\
\text { intermediate); indumentum (glabrous, strigose-hispid, glandular); calyx type (campanulate to irregularly paleaceous, } \\
\text { pappiform); inflorescence type (determinate, indeterminate, both types). }\end{array}$ \\
\hline
\end{tabular}

To detect differences between ploidy levels and morphological characters, after examining normality and homoscedasticity, we conducted a non-parametric Mann-Whitney $(U)$ test for each quantitative character examined. In the case of qualitative characters, a contingency table was performed and absolute and relative frequencies were calculated. There were calculated Chi-Square, V-Crámer and contigency coefficient statistic indexes. The Chi-Square statistic allows inference of whether variables are dependent or independent. We performed these analyses in PAST; in this program, the significance of association between two variables is given, with $P$-values from the Chi-Square distribution and a permutation test with 9999 replicates (Hammer et al. 2001); however, Chi-Square does not provide information about magnitude of the association. For this reason, we included two tests, V-Crámer and contingency coefficient, which allowed evaluation of the degree of the association, with values between 0 (no association) and 1 (perfect association).

\section{Results}

Plant identification

The characterisation of voucher specimens allowed identification of the following taxa: M. sceptrum, M. dolens subsp. dolens var. pangloea, $M$. dolens subsp. callosa, $M$. dolens subsp. rigida varieties rigescens, anisitsii and foliolosa and $M$. dolens subsp. acerba varieties rudis, acerba and latifolia. There were some intermediate specimens between the following taxa: (1) M. dolens subsp. rigida var. foliolosa and $M$. dolens subsp. acerba var. acerba; and (2) M. sceptrum and M. dolens subsp. acerba var. rudis. Some specimens were identified as $M$. aff. custodis, because they were morphologically similar to $M$. custodis, but they differed by presence of a pallid band on glabrous (or almost) leaflets (Table 1).

\section{Chromosome numbers}

The following chromosome numbers were found: $2 n=4 x=52$, for $M$. sceptrum, $M$. aff. custodis, $M$. dolens subsp. acerba var. rudis and $M$. dolens subsp. dolens var. pangloea; $2 n=8 x=104$, for $M$. dolens subsp. callosa, M. dolens subsp. rigida var. foliolosa, $M$. dolens subsp. rigida var. anisitsii, M. dolens subsp. rigida var. rigescens, $M$. dolens subsp. acerba var. aff. rudis, $M$. dolens subsp. acerba var. acerba, M. dolens subsp. acerba var. latifolia and the intermediate specimens between $M$. dolens var. acerba and M. dolens subsp. rigida (Table 1, Fig. 1).

In several cases, we found taxa with the same ploidy level growing in sympatry, sometimes with individuals exhibiting intermediate morphology (Table 3, Fig. 2). Tetraploids occur in the areas of Cerrado ecoregion from Paraguay and adjacent Brazil (generally below $900 \mathrm{~m}$ ASL), as well as in highlands with grasslands or savannas from southern Brazil (campos or campos de altitude, at 900-1200 m ASL). Octoploids are distributed throughout the studied area, i.e. southern Brazil, Paraguay and north-eastern Argentina, mainly below $900 \mathrm{~m}$ ASL (Table 1, Fig. 2).

\section{Karyotype parameters}

Karyotypes observed were symmetric with small chromosomes, generally shorter than than $3 \mu \mathrm{m}$ (Fig. 3). CLHG ranged from $11.21 \mu \mathrm{m}$ in the intermediate individuals between $M$. dolens subsp. rigida and acerba to $25.14 \mu \mathrm{m}$ in $M$. dolens var. pangloea. CLHG was normally distributed according to the results of Shapiro-Wilk's test $(W=0.92 ; P=0.1311)$ and variances were homogeneous (Levene's test: $P=0.05$ ). ANOVA showed that there were statistically significant differences among taxa (Table 4). CAHG ranged from $6.56 \mu \mathrm{m}$ in some accessions of $M$. dolens subsp. acerba var. latifolia to $27.94 \mu \mathrm{m}$ in M. dolens var. pangloea. CAHG was not normally distributed according to the results of Shapiro-Wilk's test $(W=0.84$; $P<0.05$ ). Variances were not homogeneous (Levene's test: $P<0.05)$. Non-parametric ANOVA did not detect statistically significant differences among accessions $(P=0.05)$. The $\mathrm{A}_{2}$ index ranged from 0.16 in some accessions of $M$. dolens subsp. acerba var. latifolia to 0.30 in accessions of M. dolens var. pangloea (Table 4).

\section{Morphological analysis}

Although the majority of specimens could be identified satisfactorily by using the Barneby's (1991) classification, some showed morphological variation differing from the original description or from the morphology of nomenclatural types. Specimens from highland grasslands of southern Brazil (Fortunato 9555a,e,d,e; Morales 1624, 1625, 1626, 1630) exhibited long and indeterminate inflorescences and a leaf formula similar to that of M. custodis, but they differed from its type specimen by the presence of a pallid band in the leaflet margin and few and sparse glandular trichomes. The specimens 

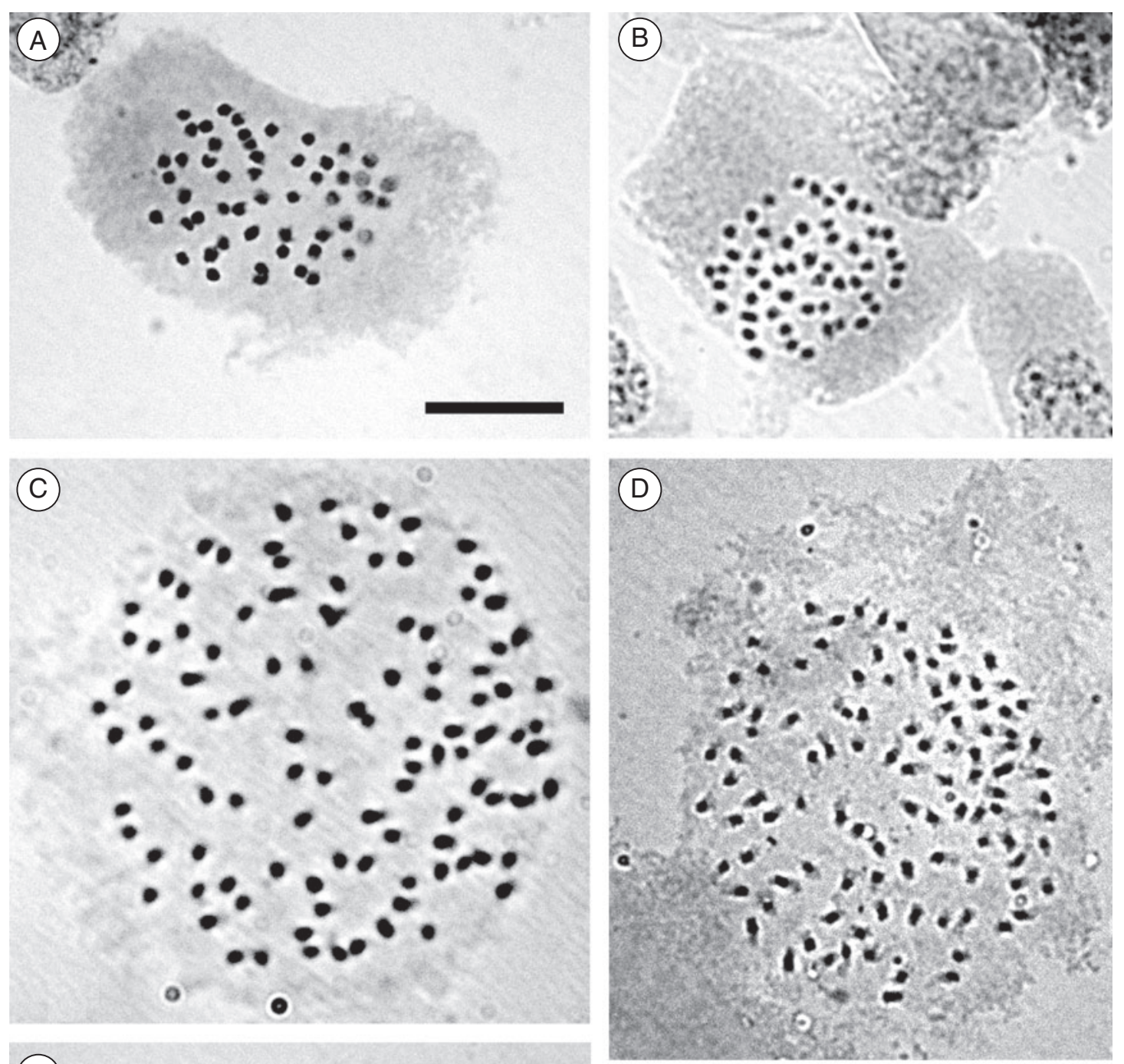

(E)
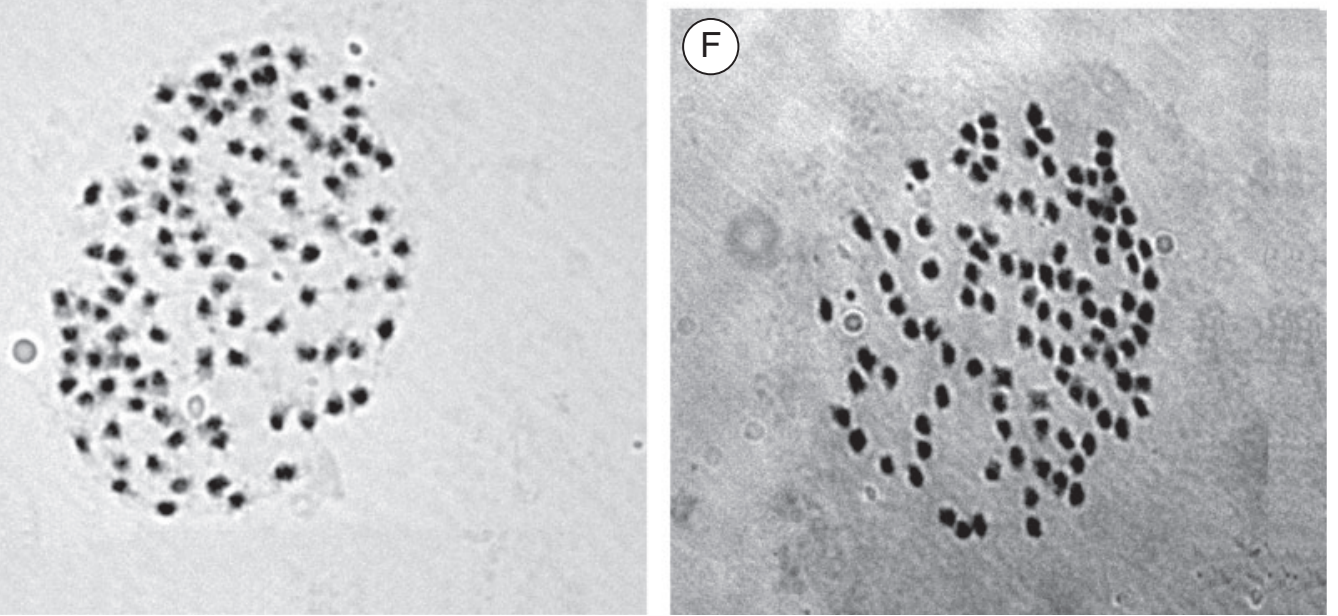

Fig. 1. Mitotic metaphases of Mimosa subseries Dolentes and Brevipedes. A. M. dolens subsp. acerba var. rudis, $4 x=52$.

B. $M$. sceptrum, $4 x=52$. C. . dolens subsp. rigida var. anisitsii, $8 x=104$. D. M. dolens subsp. acerba var. latifolia, $8 x=104$.

E. M. dolens subsp. rigida var. foliolosa, $8 x=104$. F. M. dolens subsp. callosa, $8 x=104$. Scale bar: $10 \mu \mathrm{m}$. 
Table 3. Areas of sympatry between taxa in the Mimosa subseries Dolentes-Brevipedes complex and description of the taxa and intermediate forms

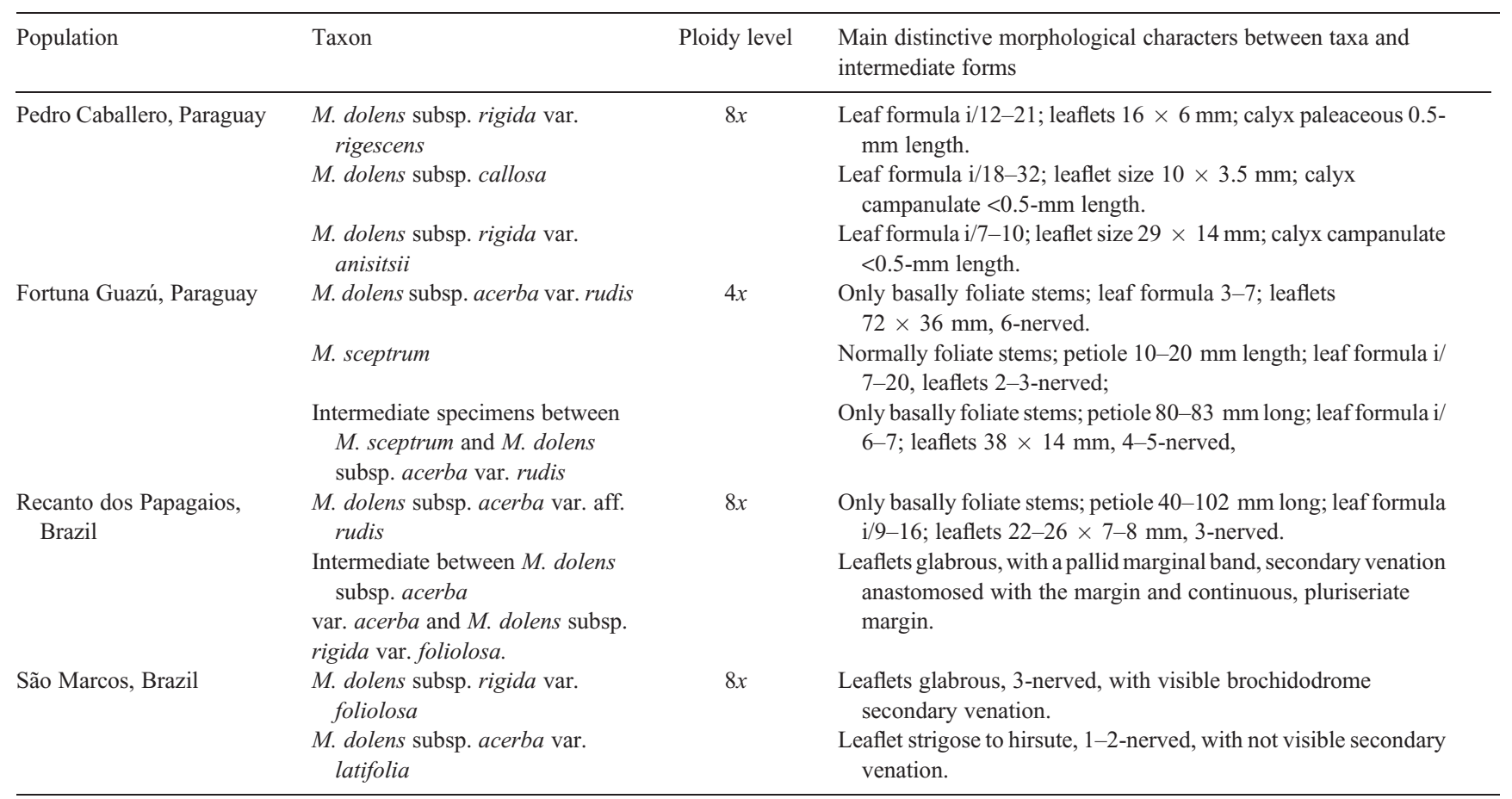

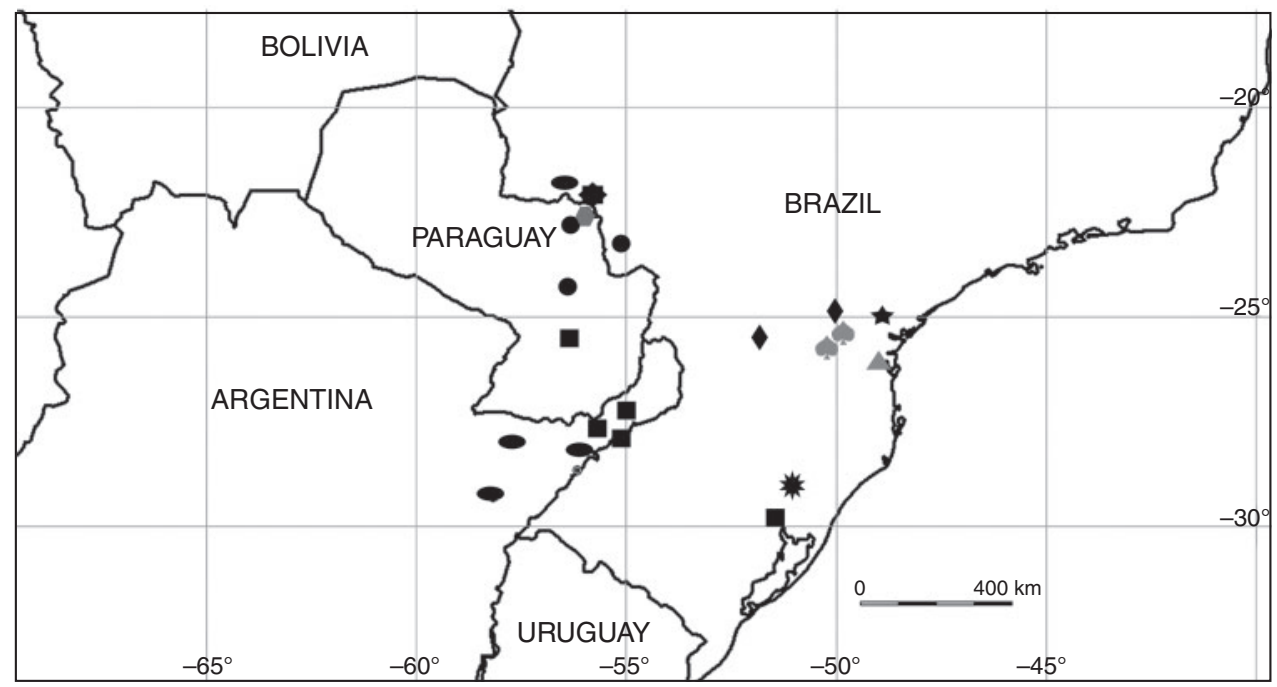

Fig. 2. Collecting sites of voucher specimens. Mimosa dolens subsp. rigida var. foliolosa (ellipses). M. dolens subsp. rigida var. anisitsii (circle). M. dolens var. pangloea (suit). M. aff. custodis (triangle). M. dolens subsp. acerba var. latifolia (square). M. dolens var. acerba (rhombus). Sympatry areas with $M$. dolens subsp. acerba var. rudis, M. sceptrum and intermediate between them (hexagon). Area of sympatry between $M$. dolens subsp. acerba vars. latifolia and rudis, and intermediate between $M$. dolens var. acerba and M. dolens subsp. rigida var. foliolosa (five-point star). Area of sympatry between $M$. dolens subsp. rigida vars. rigescens and anisitsii and M. dolens subsp. callosa (eight-point star). Area of sympatry between M. dolens subsp. acerba var. latifolia and $M$. dolens subsp. rigida var. foliolosa (ten-point star). Grey represents the tetraploid accessions and black represents the octoploid accessions.

Morales 1593 and 1594 were very close to M. dolens subsp. acerba var. rudis, and differed from it only by their petiole length, which was similar to $M$. dolens subsp. acerba var. latifolia
(Tables 3, 5). We also found intermediate specimens between (1) M. dolens subsp. acerba var. rudis and M. sceptrum, distinguished from both taxa by the intermediate leaf formula 


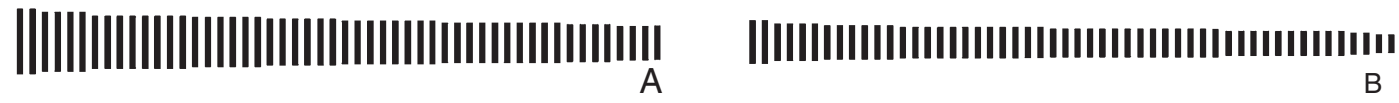

\section{|||||||||||||||||||||||||||||||||||||||||||||||||||||||||||||||||||||||||||||||||||||||||||||||||||||||||||}

Fig. 3. Idiograms of some taxa of the subseries Dolentes and Brevipedes. Entire chromosome set. A. M. dolens subsp. dolens var. pangloea, $4 x=52$. B. M. sceptrum, $4 x=52$. C. $M$ dolens subsp. callosa, $8 x=104$. Scale bar: $1 \mu \mathrm{m}$.

Table 4. Karyotype parameters in species of subseries Dolentes and Brevipedes: chromosome length per haploid genome (CLHG), chromosome area per haploid genome (CAHG) and asymmetry index $\left(\mathrm{A}_{2}\right)$

CLGH was analysed by means parametric ANOVA and post hoc pairwise comparison Tukey's test; CAHG was analysed by means non-parametric ANOVA (Kruskal-Wallis test) and pairwise comparison Mann-Whitney test. Values within a column followed by the same lower-case, superscript letter are not statistically significantly different $(P=0.05)$

\begin{tabular}{|c|c|c|c|c|c|c|}
\hline Taxon & $n$ & Accession & $\begin{array}{l}\text { Ploidy } \\
\text { level }\end{array}$ & $\begin{array}{c}\text { CLHG }(\text { mean } \pm \text { standard } \\
\text { deviation; } \mu \mathrm{m})\end{array}$ & $\begin{array}{c}\text { CAHG (mean } \pm \text { standard } \\
\left.\text { deviation; } \mu \mathrm{m}^{2}\right)\end{array}$ & $\mathrm{A}_{2}$ \\
\hline M. dolens var. acerba-M. dolens subsp. rigida intermediates & 5 & RHF9517 & $8 x$ & $11.21 \pm 1.39^{\mathrm{a}}$ & $8.55 \pm 3.92^{\mathrm{a}}$ & 0.17 \\
\hline M. dolens subsp. acerba var. latifólia & 5 & RHF9029 & $8 x$ & $11.90 \pm 3.34^{\mathrm{a}}$ & $6.56 \pm 2.37^{\mathrm{a}}$ & 0.16 \\
\hline M. sceptrum & 5 & RHF9282 & $4 x$ & $12.35 \pm 0.18^{\mathrm{a}}$ & $8.69 \pm 1.32^{\mathrm{a}}$ & 0.17 \\
\hline M. dolens subsp. rigida var. anisitsii & 5 & RHF9209 & $8 x$ & $15.49 \pm 3.97^{\mathrm{a}, \mathrm{b}}$ & $13.98 \pm 8.05^{\mathrm{a}}$ & 0.16 \\
\hline M. dolens subsp. rigida var. foliolosa & 5 & RHF9077 & $8 x$ & $15.64 \pm 3.93^{\mathrm{a}, \mathrm{b}}$ & $12.79 \pm 5.85^{\mathrm{a}}$ & 0.19 \\
\hline M. dolens subsp. acerba var. acerba & 5 & OR8212 & $8 x$ & $13.42 \pm 0.09^{\mathrm{a}, \mathrm{b}}$ & $8.66 \pm 1.00^{\mathrm{a}}$ & 0.24 \\
\hline M. dolens subsp. acerba var. rudis & 5 & RHF9279 & $4 x$ & $13.94 \pm 0.90^{\mathrm{a}, \mathrm{b}}$ & $9.88 \pm 1.07^{\mathrm{a}}$ & 0.18 \\
\hline M. dolens subsp. rigida var. rigescens & 5 & RHF9347 & $8 x$ & $14.93 \pm 1.14^{\mathrm{a}, \mathrm{b}}$ & $8.43 \pm 0.27^{\mathrm{a}}$ & 0.17 \\
\hline M. dolens subsp. acerba var. latifolia & 5 & RHF8548 & $8 x$ & $17.53 \pm 3.59^{\mathrm{a}, \mathrm{b}}$ & $16.12 \pm 7.15^{\mathrm{a}}$ & 0.29 \\
\hline M. dolens subsp. acerba var. latifolia & 5 & RHF9006 & $8 x$ & $17.89 \pm 3.00^{\mathrm{a}, \mathrm{b}}$ & $14.44 \pm 4.26^{\mathrm{a}}$ & 0.24 \\
\hline M. custodis & 5 & RHF9555 & $4 x$ & $21.76 \pm 3.17^{\mathrm{a}, \mathrm{b}}$ & $13.28 \pm 1.49^{\mathrm{a}}$ & 0.28 \\
\hline M. dolens var. pangloea & 5 & MM1657 & $4 x$ & $21.13 \pm 2.44^{\mathrm{a}, \mathrm{b}}$ & $17.73 \pm 3.68^{\mathrm{a}}$ & 0.30 \\
\hline M. dolens var. pangloea & 5 & RHF9597 & $4 x$ & $25.14 \pm 1.80^{\mathrm{b}}$ & $27.94 \pm 2.98^{\mathrm{a}}$ & 0.20 \\
\hline
\end{tabular}

and intermediate leaflet size, and (2) M. dolens var. acerba and $M$. dolens subsp. rigida var. foliolosa, distinguished from both taxa by the intermediate pubescence (Tables 3, 5). Many specimens of $M$. dolens exhibited indeterminate inflorescences but they can be assigned to subseries Dolentes because of their general morphology (Table 5, Fig. 4).

Five groups were distinguished at 0.75 similarity (Fig. 4) and their morphology is compared in Tables 5 and 6. Selected univariate statistics are given in Tables 6 and A3).

Non parametric tests were performed based on the properties of quantitative variables, such as normality and homocedasticity revealed by Shapiro-Wilk and Levene's tests (Tables A1, A2). The main differences among groups were mostly in qualitative characters, but also in some quantitative characters, which allowed taxa or groups with statistically significant differences (Tables 6, A3) to be distinguished. The only quantitative character that did not differ significantly among taxa was the number of nodes per inflorescence (Table 6).

The Mann-Whitney pairwise comparison test showed significant differences among several groups. Pod-cluster diameter showed the most significant differences between Groups 1 and 2 and the remainder. Group 2 exhibited significant differences in peduncle length with all groups. Group 3 could be distinguished from the remainders especially by its number of leaflets per pinna, number of visible primary veins, and petiole : rachis ratio. Group 4 exhibited the largest differences, especially with Groups 1 and 5, in capitula per inflorescence. Both Group 3 and Group 4 showed most significant differences in visible primary veins per leaflet. Group 5 exhibited the largest differences from remainder of taxa in petiole length, pinnae rachis length, size of leaflets (width and length; Tables 6, A3).

The five groups observed in the UPGMA cluster analysis (Fig. 4, Table 5) are characterised as follows.

\section{Group 1}

Mimosa dolens var. pangloea: presence of armed stems, indumentum with densely glandular trichomes, leaflets with glandular margin and glabrous surfaces and paired inflorescences, with pod clusters generally very small (mean cluster diameter: $13.47-13.87 \mathrm{~mm}$ ). This group of individuals was tetraploid $(2 n=4 x=52)$.

\section{Group 2}

Mimosa aff. custodis, M. dolens var. acerba and intermediate forms with $M$. dolens subsp. rigida: unarmed stems, eglandular indumentum and leaflets with variable pubescence and venation, but constantly with presence of a pallid marginal band on the leaflets. This group exhibited very short peduncles (mean length: $8.13 \mathrm{~mm}$ ) and small pod clusters (arithmetic mean of cluster diameters: $13.19-14.16 \mathrm{~mm}$ ). This set of individuals were tetraploid $(2 n=4 x=52)$ and octoploid $(2 n=8 x=104)$. 


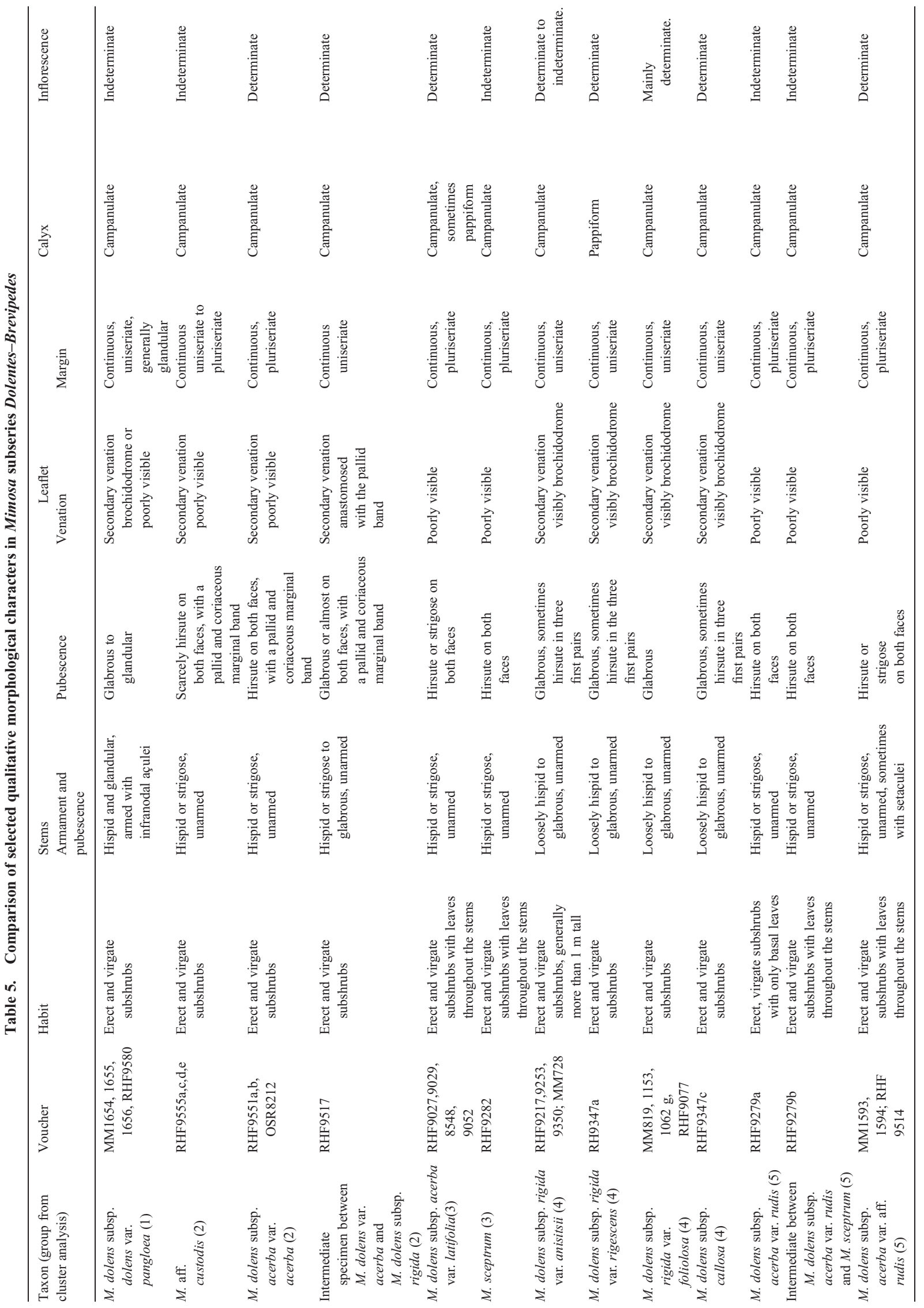




\section{Group 3}

Mimosa dolens subsp. acerba var. latifolia and M. sceptrum: presence of regularly foliated stems, leaflets with hirsute or strigose pubescence and secondary venation not visible and absence of a pallid marginal band. This group exhibited the largest number of leaflets per pinna (9-24), relatively short petioles in relation to the pinna rachis (mean petiole : rachis of ratio $6: 1$ ) as well as few visible primary veins $(1-3)$ per leaflet. Individuals studied were tetraploid $(2 n=4 x=52)$ and octoploid $(2 n=8 x=104)$.

\section{Group 4}

Mimosa dolens subsp. rigida and subsp. callosa: glabrous leaflets with visibly brochidodrome venation and continuous, uniseriate margin. In addition, Group 4 exhibited the largest number of visible primary veins per leaflet (2-5) and the smallest number of nodes and capitula per inflorescence (mainly $1-7$, in one specimen up to 25). This group was octoploid $(2 n=8 x=104)$.

\section{Group 5}

Mimosa dolens subsp. acerba var. rudis and close specimens: presence of only basally foliated stems, leaflets with hirsute or strigose pubescence and pluriseriate margin and no visible secondary venation. In addition, this group can be distinguished by having the largest leaves, with petioles and pinnae rachis very long (mean petiole length: $44.94 \mathrm{~mm}$ and rachis length: $86.23 \mathrm{~mm}$ ) and large leaflets (mean length: $22.76 \mathrm{~mm}$, and width: $7.59 \mathrm{~mm})$. Individuals were tetraploid $(2 n=2 x=52)$ or octoploid $(2 n=8 x=104)$.

The $U$-test was chosed based on Levene's test (Table A4), detecting statistically significant differences between tetraploid and octoploid accessions in the number of leaflet pairs per pinna, number of capitula and nodes per inflorescence, peduncle length and legume clusters diameter, whereas the remaining characters did not show statistically significant differences (Table 7, Fig. 4). The analysis of qualitative characters showed that indumentum, pubescence of leaflets, armament of stems, inflorescence type and presence of glandular trichomes were associated differently from ploidy levels, whereas the remaining qualitative characters did not show an association (Tables 5, 8).

\section{Discussion}

\section{Chromosome numbers and karyotype parameters}

The present results in the Mimosa subseries Dolentes-Brevipedes complex supported that $x=13$ is the basic chromosome number of the genus, as was previously postulated (Isely 1971), and supported in more recent works (Goldblatt 1981; Seijo 1993, 1999, 2000; Seijo and Fernández 2001; Morales et al. 2010, 2011, 2012, 2014a, 2014b; Dahmer et al. 2011). The accessions studied here were all polyploid, namely, tetraploid and octoploid. Polysomaty appears in the species of Mimosa subseries Dolentes and Brevipedes, as has also been reported frequently for other members of Mimosa (Seijo 1993, 1999; Seijo and Fernández 2001; Morales et al. 2010, 2014a; Dahmer et al. 2011; Olkoski and Schifino-Wittmann 2011).

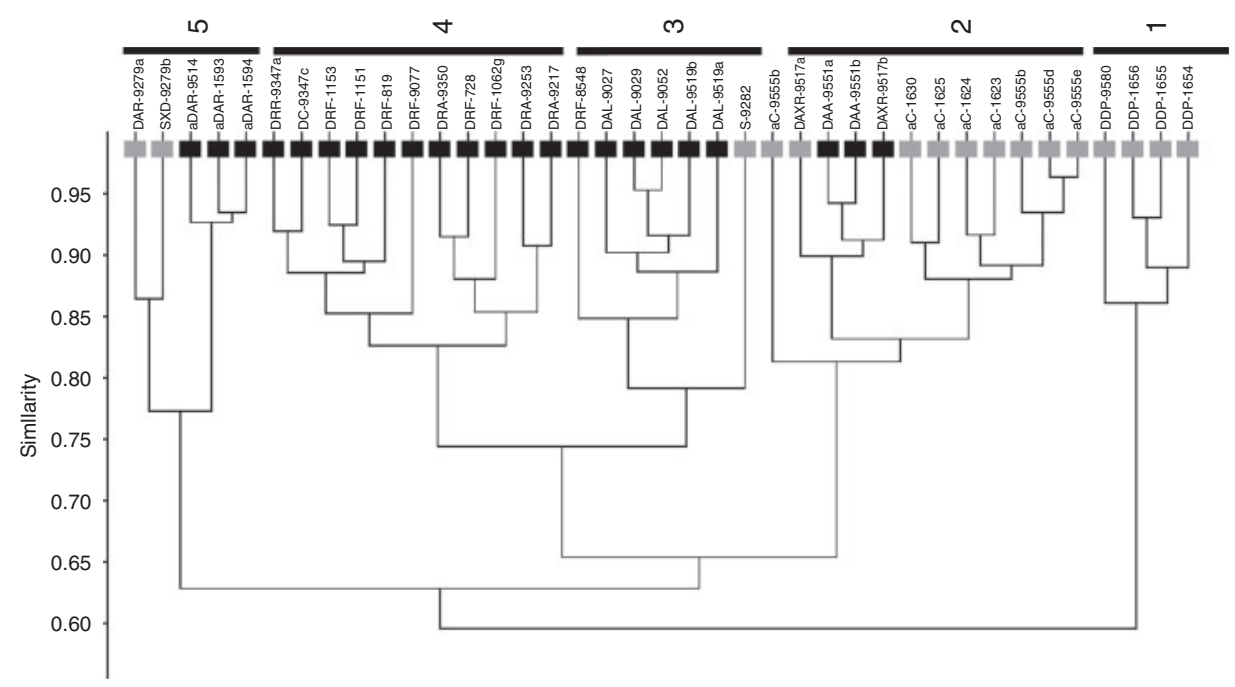

Fig. 4. Hierarchical cluster analysis in Mimosa subseries Dolentes and Brevipedes, unweighted pair-group method using arithmetic averages (UPGMA) based on mixed similarity measures. Alphanumerical code indicates the taxon and (contained within parentheses) collection initials and collection number: DAR, Mimosa dolens subsp. acerba var. rudis; aDAR, Mimosa dolens subsp. acerba var. aff. rudis; SxD, Intermediate between M. sceptrum and M. dolens subsp. acerba var. rudis; DRR, Mimosa dolens subsp. rigida var. rigescens; DRF, $M$. dolens subsp. rigida var. foliolosa; DRA, M. dolens subsp. rigida var. anisitsii; DAL, Mimosa dolens subsp. acerba var. latifolia; S, M. sceptrum; aC, M. aff. custodis; DAA, Mimosa dolens subsp. acerba var. acerba; DAXR, intermediate between M. dolens var. acerba and M. dolens subsp. rigida; DDP, M. dolens subsp. dolens var. pangloea. Grey squares indicate tetraploid accessions; dark squares indicate octoploid accessions. Bars and numbers represent clusters. 


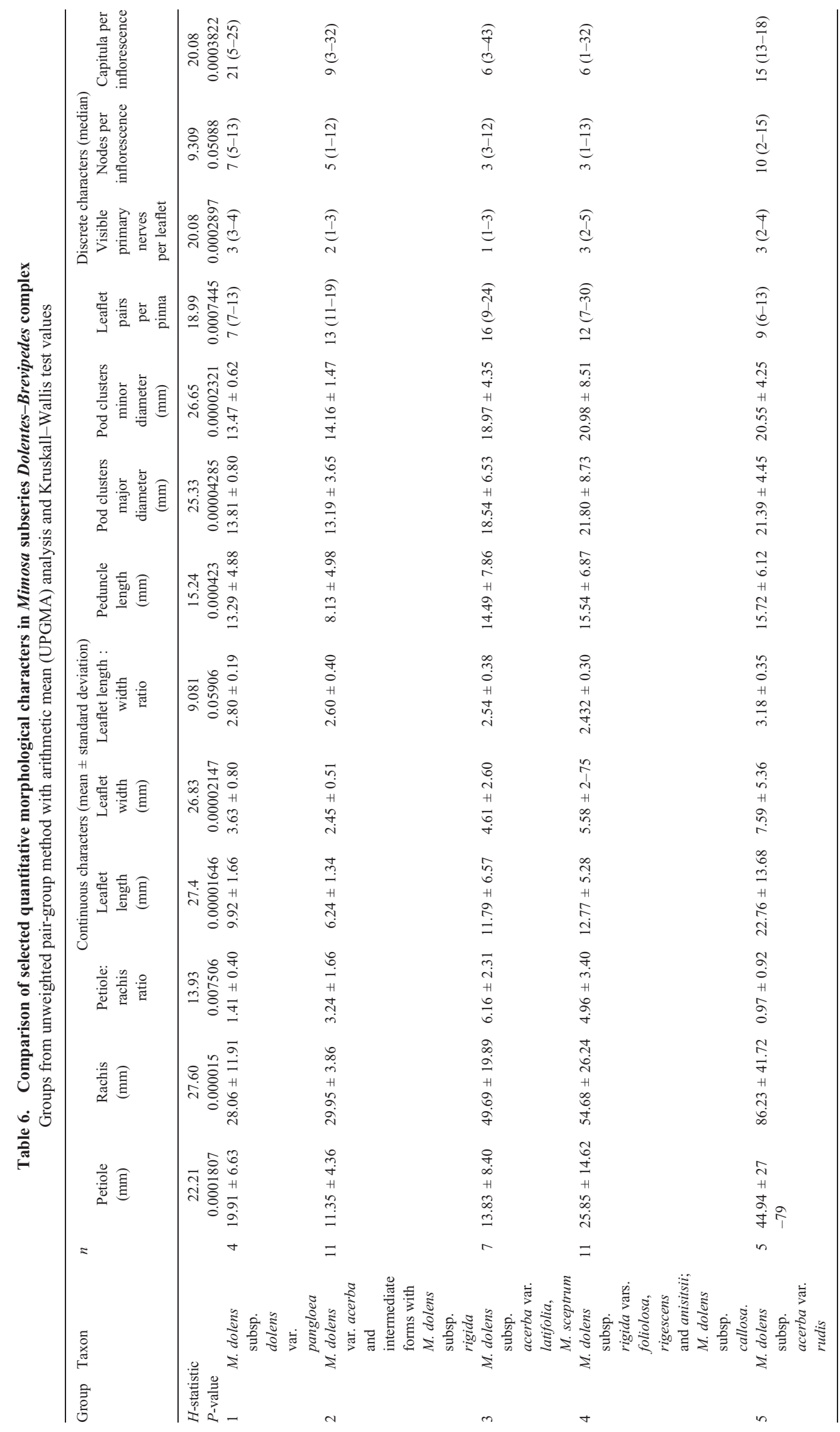


Table 7. Differences between ploidy levels in quantitative morphological characters in Mimosa subseries Dolentes and Brevipedes Mann-Whitney test statistically significant differences are: ${ }^{*}, P<0.05$

\begin{tabular}{|c|c|c|c|c|c|}
\hline Character type & Character & $4 x$ & $8 x$ & $U$-value & $P$-value \\
\hline \multirow[t]{10}{*}{ Quantitative, continuous } & \multicolumn{5}{|c|}{ Mean \pm standard deviation } \\
\hline & Petiole length (mm) & $25.94 \pm 25.41$ & $18.93 \pm 15.38$ & 145.00 & 0.3191 \\
\hline & Rachis, length (mm) & $42.66 \pm 27.76$ & $68.72 \pm 32.61$ & 84.00 & $0.0058^{*}$ \\
\hline & Leaflet length (mm) & $15.27 \pm 17.78$ & $14.31 \pm 7.67$ & 142.00 & 0.2789 \\
\hline & Leaflet width (mm) & $6.60 \pm 8.82$ & $5.91 \pm 3.53$ & 138.00 & 0.2385 \\
\hline & Leaflet, ratio length : width & $2.53 \pm 0.36$ & $2.52 \pm 0.43$ & 168.00 & 0.7399 \\
\hline & Peduncle length (mm) & $11.78 \pm 4.1$ & $20.14 \pm 12.81$ & 88.50 & 0.0087 \\
\hline & Legume cluster largest diameter (mm) & $15.66 \pm 2.65$ & $23.99 \pm 6.51$ & 40.50 & $5.9800 \times 10^{-5 *}$ \\
\hline & Legume cluster smallest diameter (mm) & $14.60 \pm 2.77$ & $23.04 \pm 6.18$ & 26.50 & $9.9380 \times 10^{-6 *}$ \\
\hline & \multicolumn{5}{|c|}{ Median (minimum-maximum range) } \\
\hline \multirow{4}{*}{ Quantitative, discrete } & Number of leaflet pairs per pinna & $11(5-16)$ & $13(8-30)$ & 87.5 & $7.70 \times 10^{-3 *}$ \\
\hline & Visible primary nerves per leaflet & $2.5(1-4)$ & $3(1-6)$ & 170.5 & 0.7895 \\
\hline & Heads or fruit clusters per inflorescence axis & $7(13-2)$ & $3(1-15)$ & 69.0 & $0.0124 *$ \\
\hline & Nodes per inflorescence axis & $17(4-43)$ & $5(1-25)$ & 52.0 & $2.0929 \times 10^{-4 *}$ \\
\hline
\end{tabular}

Table 8. Association measures between qualitative morphological characters and cytotypes in Mimosa subseries Dolentes and Brevipedes

\begin{tabular}{llccc}
\hline Type of character & Character (states) & Chi-Square $\left(\chi^{2}\right)$ & V-Crámer & Contingency coefficient \\
\hline Qualitative, nominal & Habit (virgate efoliate stems; normally foliate stems) & 0.8947 & 0.0255 & 0.0255 \\
& Leaflet pubescence (strigose, glabrous, intermediate, glandular) & 0.0012 & 0.7687 & 0.1585 \\
& Leaflet margin & 0.4102 & 0.4114 \\
& Leaflet secondary venation (brochidodrome, not visible, & 0.1875 & 0.1565 \\
& $\quad$ anastomosed with pallid band, intermediate between them) & & 0.3883 \\
& Indumentum (glabrous, strigose-hispid, glandular) & 0.0005 & 1.0000 \\
Qualitative, binomial & Inflorescence type (determinate, indeterminate) & 0.0002 & 0.8058 & 0.7416 \\
& Glandular trichomes (presence or absence) & 0.0002 & 0.0020 & 0.5933 \\
& Stem armament (armed or unarmed) & 0.4835 & 0.1348 & 0.6275 \\
& Marginal pallid band of leaflet (presence or absence) & & 0.1336 \\
\hline
\end{tabular}

The following chromosome numbers are new reports: $2 n=4 x=52$, for $M$. dolens var. pangloea, M. sceptrum, $M$. aff. custodis, $M$. dolens subsp. acerba var. rudis; $2 n=8 x=104$, for $M$. dolens subsp. callosa, $M$. dolens subsp. rigida var. foliolosa, M. dolens subsp. rigida var. rigescens, M. dolens subsp. acerba var. aff. rudis and $M$. dolens subsp. acerba var. latifolia. The present results confirmed the chromosome number $2 n=8 x=104$ for $M$. dolens subsp. acerba and subsp. rigida (Seijo 1993).

The chromosomes studied were very small (CLGH generally $<18 \mu \mathrm{m}$ ), in concordance with previous results in other taxa of Mimosa (Morales et al. 2010, 2011, 2014a, 2014b). There is a slight difference in chromosome size between tetraploid M. dolens subsp. dolens var. pangloea, which had the largest chromosomes, and the rest of the taxa examined (Table 4).

In this complex, tetraploids do not differ significantly from octoploids in chromosome size, with the exception of a few accessions. Our data suggested that some tetraploids from campos de altitude, i.e. highland grasslands from 900 to $1200 \mathrm{~m}$ ASL, seem to have larger chromosomes than do tetraploids from Cerrado and all octoploids analysed. Differences in chromosome size could be related to differences in genome size. Variations in chromosome size (and, eventually, in genome size) occur in distant clades or taxonomic groups of
Mimosa, and a decreasing chromosome size seems to be frequently associated with increasing ploidy levels (Morales 2011; Morales et al. 2011). Variations in chromosome size, as well as polyploidy (Dahmer et al. 2011; Morales et al. 2014a, $2014 b$ ), have arisen via independent events throughout the evolutionary history of the genus and in different events within infrageneric groups.

The $\mathrm{A}_{2}$ index is very similar in all taxa studied, which indicates that the chromosome size in the same complement is uniform, consistent with all species of Mimosa that we studied previously (Morales et al. 2011, 2014a, 2014b). Karyotype appears to be relatively symmetric in all studied taxa, with little variation in size among chromosome pairs (Table 4).

\section{Morphology and cytogenetics}

The combination of a typical habit (erect subshrubs with efoliate pseudoracemes), mainly one-jugate pinnae, espiculate leaves, indeterminate inflorescence, and tetramerous, diplostemonous flowers, allows identification of the specimens as members of either subseries Dolentes or Brevipedes (Barneby 1991). Sometimes it is difficult to distinguish between both these subseries. Barneby (1991, pp. 510-515) suggested a differentiation of Dolentes and Brevipedes by their 
inflorescences, which are determinate and indeterminate respectively, but we found some intermediate forms between them; critical individuals were observed previously either in herbarium specimens or in the field (Morales 2011).

We found some specimens with indeterminate inflorescences but resembling Dolentes in habit, leaf morphology, and in having dense clusters of pods; the analysis of these specimens and their comparison with the nomenclatural types of taxa prevented us from classifying them effectively using to the scheme of Barneby (1991, pp. 510-515).

The individuals with indeterminate inflorescences and glabrous leaflets with uniseriate margins should strictly be identified as members of subseries Brevipedes. However, those specimens cannot be included in that subseries because their morphology is not consistent with any of the described members of subseries Brevipedes, according to Barneby (1991, pp. 705-716). The overall morphology resembles M. dolens subsp. rigida and they should be considered as members of that taxon. The individuals with indeterminate inflorescences but strigose or hirsute leaflets with pluriseriate, setose margins and no visible secondary venation could be classified in different taxa, according to Barneby (1991, pp. 510-515, 582-583, 706-707), as M. sceptrum, M. aff. custodis or M. dolens subsp. acerba var. rudis. In addition, all the specimens classified as M. dolens var. pangloea differ from it only by having indeterminate inflorescences.

Unweighted pair-group method with arithmetic mean grouped the individuals in the following five main clusters: a cluster with $M$. dolens var. pangloea; a second cluster with members of subseries Dolentes and Brevipedes with a pallid band in the margin of leaflets; a third cluster with members of both subseries exhibiting hirsute or strigose leaflets; a fourth cluster comprising the members with glabrous leaflets; and a fifth cluster with members with large leaves and largely efoliate stems. This grouping pattern is not concordant with the infrageneric circumscription of Barneby (1991, pp. 510-515) because the members of subseries Brevipedes are not distinguished from similar members of subseries Dolentes by indeterminate inflorescence.

The groups detected by UPGMA analysis are partially concordant with the infraspecific treatment of Barneby (1991, pp. 582-583) of M. dolens. The separation of the subspecies acerba and ssp. rigida appears to be consistent, but $M$. dolens subsp. callosa seems to be grouped together with $M$. dolens subsp. rigida. Definition of $M$. dolens subsp. callosa, exclusively on the number of leaflet pairs (Barneby 1991, pp. 582-583), should be revised because their individuals do not differentiate into clusters.

There are some intermediate specimens among taxa that were collected in areas where species occur in sympatry. A transitional form, between M. sceptrum and M. dolens subsp. acerba var. rudis, was observed. Intermediate individuals were observed growing in biotic sympatry with individuals of both taxa, suggesting a possible hybrid zone. In the UPGMA analysis, it was observed that these intermediates clustered together with M. dolens subsp. acerba var. rudis because of the habit, but other characters are exclusive to M. sceptrum.

Intermediate individuals between $M$. dolens subsp. acerba var. acerba and $M$. dolens subsp. rigida were found in several areas of southern Brazil. These specimens had leaflets that are glabrous, but exhibit a pallid marginal band. UPGMA grouped them with $M$. dolens var. acerba, suggesting that the presence of the marginal band is a trait with taxonomic value. In addition to the pallid marginal band on leaflets, that set of specimens exhibits short peduncles. All of them (var. acerba and intermediate) are octoploid and clustered together, suggesting the circumscription of $M$. dolens var. acerba would be different from the circumscription of this taxon according to Barneby (1991, pp. 582-583); it should include individuals with glabrous leaflets exhibiting the marginal band (Fig. 4).

The groups defined by morphology are not directly correlated with the ploidy level, because the clusters can comprise tetraploid, octoploid or both cytotypes. We could infer associations between morphological characters and ploidy levels, especially in indumentum, leaf formula, inflorescence and fruit.

Among the accessions studied, an indumentum with profuse glandular trichomes appears exclusively in the tetraploid $M$. dolens var. pangloea, as was previously observed (Barneby 1991, pp. 582-583, 589-590; Morales 2011; Grohar et al. 2016), but glands can also be found in $M$. aff. custodis (also tetraploid). All the octoploids analysed here have an eglandular indumentum. We have hypothesised that evolution of trichomes in Mimosa involves unidirectional events of transformation, from eglandular to glandular trichomes (Santos-Silva et al. 2013). Thus, in the subseries Dolentes and Brevipedes, tetraploid taxa with glandular trichomes would be plesiomorphic in comparison to octoploid taxa with eglandular trichomes. We observed that the field populations of tetraploid glandular and octoploid eglandular M. dolens that are separated by a few kilometres exhibit gene flow between them and show similar genetic structure (similar genetic groups inferred by means of Bayesian analyses from amplified fragment length polymorphism (AFLP) data, according to Morales et al. 2016). We hypothesise that these tetraploids are ancestors of their closest octoploids.

There is also an association between ploidy levels and pubescence of leaflets; all tetraploids had strigose, hirsute or glandular, i.e. non-glabrous, leaflets. We also observed another association between ploidy levels and the pubescence of leaflets; all tetraploids had strigose, hirsute or glandular, i.e. non-glabrous, leaflets; in opposition, octoploids included taxa that mostly have only glabrous leaflets, such as $M$. dolens subsp. rigida (Barneby 1991, pp. 582-583).

The combination of indeterminate inflorescences with small clusters of pods on short peduncles appears mainly in tetraploids (Fig. 4, Table 5), whereas the combination of determinate inflorescences and pods grouped in dense and large clusters on relatively longer peduncles (which would correspond to subseries Dolentes sensu stricto according to Barneby 1991, pp. 578-580) appears exclusively in octoploids.

Although it is possible to observe a great variation in pair number, size and venation of leaflets in $M$. subseries Dolentes and Brevipedes, there are mostly no obvious correlations between leaflet morphology and ploidy level. Each of the cytotypes exhibits a broad range of leaflet size and leaf formula, with extremes from few- and large-leaved (M. dolens subsp. rigida var. anisitsii, $M$. dolens var. rudis) to many and small-leaved leaflets (M. aff. custodis, M. dolens subsp. callosa, M. dolens 
subsp. acerba var. latifolia). Nevertheless, tetraploids were almost all few-leaved (Table 5).

A pappiform calyx was observed only in M. dolens subsp. rigida var. rigescens, as well as in some accessions of $M$. dolens subsp. acerba (all octoploids), but there are still insufficient data to make inferences about variation of this character with the ploidy level. Likewise, in some populations of $M$. dolens var. latifolia, it was possible to observe minute setaculei in the stems, resembling a transition to $M$. dolens subsp. dolens, but this character did not seem to be associated with changes in the chromosome number.

\section{Cytogeography}

The geographic pattern of the cytotypes shows that tetraploids occur mainly at low latitudes from 22 to $26^{\circ} \mathrm{S}$, in Cerrado and campos of southern Brazil and Paraguay, whereas octoploids occur in a wider range of distribution, at higher latitudes, from 22 to $29^{\circ} \mathrm{S}$, in campos and savannas from southern Brazil and north-eastern Argentina (Fig. 2). This pattern (ploidy levels increasing with latitude) appears to be similar to those seen in other taxa in the genus, including M. debilis Humb. and Bonpl. ex Willd. (Morales et al. 2010), section Batocaulon series Stipellares Benth. (Seijo 1993, 1999; Morales et al. 2011, $2014 a$ ), and, in a broader sense, the southernmost area of distribution of Mimosa (Seijo and Fernández 2001; Morales et al. 2014a).

The tetraploid entities, M. sceptrum, M. aff. custodis and M. dolens var. rudis (although the last also has some octoploids) are native to campos de altitude and Cerrado and they seem to be restricted to these environments. In contrast, almost all octoploid entities, including $M$. dolens subsp. acerba var. latifolia, M. dolens subsp. acerba var. acerba, M. dolens subsp. callosa and M. dolens subsp. rigida, show a larger distributional range than that of tetraploids. The areas where tetraploids and octoploids overlap (campos de altitude and Cerrado in Amambay slopes) are considered centres of diversification of the Mimosa subseries Dolentes and Brevipedes, which could infer from Barneby (1991, pp. 712-713) and our recent data (Morales 2011), because of the high number of taxa occurring there.

Octoploids appear to be expanding to the southernmost areas of distribution of these subseries, where they could be the predominant cytotype, according to our studies (Fig. 2). We hypothesise that polyploidy plays an important role in the expansion or colonisation and adaptation to new environments, at least in the southernmost diversified groups of Mimosa. Our conclusions are supported by a representative number of chromosome counts covering most of the distribution range of this complex, including the greatest centres of diversification at present known, namely, Paraná State (Brazil) and the slopes of Sierra del Amambay, in the Brazil-Paraguay border (Barneby 1991, p. 581; Morales 2011).

A more widespread distribution of polyploids, in comparison with diploids or individuals with lower ploidy levels, was observed in several families of vascular plants in the northern hemisphere (Stebbins 1984; Brochmann et al. 2004; Majure et al. 2012). The presence or predominance of polyploids at highest latitudes was frequently related to colonisation in inter-glacial periods of Pliocene and Pleistocene by high-ploidy level individuals (Stebbins 1971). According to molecular data (Simon et al. 2011), M. dolens and allied species diverged at c. 5 million years ago. Consequently, climatic variations in the Quaternary could be a feasible explanation for the present distribution of the cytotypes in the subseries DolentesBrevipedes complex.

\section{Classification of the polyploid complex}

The presence of a set of individuals and populations that are morphologically similar, with intermediate forms among the taxa, high ploidy levels and apparent absence of diploids, suggests the presence of an extensive taxonomic and polyploid complex in the subseries Dolentes-Brevipedes, which could be classified as a declining or relictual complex, categories described by Stebbins (1971).

Stebbins (1971) mentioned that relictual polyploid complexes are defined by the absence of the diploid ancestors, which would be extinct, and declining complexes are polyploid complexes that have some related diploid that would not be the direct ancestor. The taxonomic groups including relictual complexes, such as Sequoia sempervirens Endl. (Stebbins 1971; Scott et al. 2016), Lactoris fernandeziana Phil. (Bernardello et al. 1999) and Bischofia javanica Blume (Hans 1973) are generally monotypic or ditypic genera whose possible ancestors are extinct.

In the case of the Mimosa subseries Dolentes-Brevipedes complex, the diploid ancestors are not known, but it is possible to find diploids in distant clades of the phylogenetic trees of Simon et al. (2011) in Mimosa. For this reason, this complex could be catalogued as a declining polyploid complex.

Diploids may exist as relicts at the northern extremes of the distribution (some areas of Cerrado and highland grasslands from São Paulo and Minas Gerais), for which chromosome data are sparse. Nevertheless, the M. subseries Dolentes-Brevipedes complex would not be a young polyploid complex, because the polyploids are largely distributed throughout the area of distribution of this complex. There are some polyploid complexes in the genus Mimosa that should be classified as a young complex or youthful-mature complex according to Stebbins (1971), such as the M. debilis complex, which has two cytotypes, diploid and tetraploid; in this group of taxa, both ploidy levels seem to be occupying different ecological niches but they are sympatric in some areas (Morales et al. 2010).

Another possible explanation for the lack of diploids would be ancestral polyploidisation, because current members of M. subseries Dolentes and Brevipedes could have originated from tetraploid ancestors within $M$. section Mimosa. Clade X, according to the phylogenetic reconstruction of Simon et al. (2011), is composed of several members of section Mimosa, including $M$. dolens, which are predominantly polyploid (Seijo 1993, 1999; Seijo and Fernández 2001; Morales et al. 2010, 2011, 2012, 2014a, 2014b; Dahmer et al. 2011). That clade represents mainly the southernmost representatives of the genus from subtropical and temperate regions of South America.

Tetraploids that are restricted to Cerrado and campos de altitude (M. sceptrum, M. custodis, M. dolens subsp. acerba var. rudis) from lower latitudes could be ancestors of 
octoploids that are highly dispersed throughout campos from southern Brazil, north-eastern Argentina and Paraguay (low and higher latitudes). It is possible that chromosome duplication occurred in the southern areas of Cerrado ecoregion and highland grasslands, with formation of octoploids, which later expanded to the southernmost areas, colonising the campos and savannas of southern extreme of Brazil, Argentina, and Paraguay.

The morphological diversity in both cytotypes may be due to some degree of hybridisation among taxa in DolentesBrevipedes, given the presence of intermediate specimens among specific and infraspecific taxa. These intermediates occur only in sympatric areas (which are common in the subseries Dolentes-Brevipedes overall distributional area), suggesting a hybrid-zone pattern. In all sampling sites, we found only one cytotype, but it is expected that there would be areas of contact between cytotypes, given their vicinity in the southernmost Cerrado and campos from south-eastern Brazil. However, octoploids can be also almost morphologically identical to the tetraploids, which could be explained by the presence of polyploids with different origins.

Octoploids can originate by tetraploid $\times$ hexaploid or diploid $\times$ hexaploid crosses (Katsiotis and Forsberg 1995). However, we have observed neither hexaploids nor odd polyploids in the Mimosa subseries Dolentes-Brevipedes complex, suggesting that the origin of the octoploids that we detected could be from unreduced gametes of tetraploid individuals, another mechanism for octoploid genesis (Sanderson 2011). The multidisciplinary study of contact zones between the tetraploid and octoploid cytotypes is a very promising for understanding the evolutionary biology of the genus Mimosa in southern South America, because these cytotypes can generate hybrids that could be sterile (Sanderson 2011).

\section{Conclusions}

The subseries Dolentes and Brevipedes form a taxonomic and relictual, polyploid complex. The complex includes several taxa with high morphological variation and intermediate forms among them. This complex is formed by tetraploid taxa, including members of both subseries, and octoploid taxa, which includes exclusively members of subseries Dolentes. According to morphological studies, chromosome duplication could be associated with several morphological changes in the vegetative organs, as well as in the inflorescence and fruit; tetraploids show indeterminate inflorescences with small clusters of pods, and octoploids mostly have determinate inflorescences with larger clusters of legumes. Octoploid cytotypes are widely distributed across the distributional area of this complex, whereas tetraploid cyotypes appear to be restricted to certain environments and lower latitudes.

In Mimosa subseries Dolentes and Brevipedes, the presence of intermediate forms suggests the existence of polyploids of different origin. Because of the confusing circumscription of the taxonomic entities, it is necessary to generate a new taxonomic proposal revising the rank of the published infrageneric taxa, from subseries to varieties. This might require analyses of intra- and inter-populational variation.
The comparatively high diversification of octoploids in ecology and morphology suggests that polyploidy, and potentially hybridisation, appear to be relevant in the adaptation, dispersion and evolution of this taxonomic complex of Mimosa in their southernmost areas of distribution.

In spite of detailed taxonomic study, further sampling in $M$. subseries Brevipedes is needed to confirm the findings and inferences of the present study. The situation has been confounded by a proliferation of infrageneric taxa in Mimosa, with most species known only by their nomenclatural types. Future study should also involve sampling of the hypothesised hybrids and parents using next-generation sequencing and associated population-genetics analysis to test our hypotheses.

\section{Conflicts of interest}

The authors declare that they have no conflicts of interest.

\section{Acknowledgements}

We are grateful for help with fieldwork from our collaborators, especially Guillermo Seijo, Esteban Meza Torres, Juan Manuel Rodríguez (Argentina), Osmar Ribas, Felipe Gonzatti, Eduardo Valduga, Marcos Grizzon, Luciana Scur (Brazil) and Rosa Degen, Fátima Mereles, Lidia Pérez and Graciela Céspedes (Paraguay), as well as all the staff of BAB, FCQ, HUCS and MBM herbaria. We are also indebted for assistance to the staff of Laboratory of Cytogenetics and Evolution (Facultad de Ciencias Exactas y Naturales, Universidad de Buenos Aires), especially Arturo Wulff, eminent colleague who worked hardly from many years ago to the present, accompanying us in all research activities related to the evolution of the genus Mimosa. Collection trips, visit to herbaria and research activities were funded by Myndel Botanica Foundation (Grants 2005, 2008, 2009 and 2010), CONICET (Consejo Nacional de Investigaciones Científicas y Técnicas, Argentina, PIP5560 given to R. H. Fortunato; 5927 given to L. Poggio, and 11220110100250 given to Ana Anton and R. H. Fortunato), Agencia de Promoción Científica y Tecnológica, Argentina (PICT 2011 821, given to M. Morales), Universidad de Buenos Aires, Argentina (UBACYTX178, given to L. Poggio) and Universidad de Morón (PID B06-001-06 given to M. Morales, and 06005/12 given to R. F. Fortunato).

\section{References}

Azani N, Babineau M, Bailey CD, Banks H, Barbosa AR, Pinto RB, Boatwright JS, Borges LM, Brown GK, Bruneau A, Candido E, Cardoso D, Chung KF, Clark RP, Conceição A de S, Crisp M, Cubas P, Delgado-Salinas A, Dexter KG, Doyle JJ, Duminil J, Egan AN, de la Estrella M, Falcão MJ, Filatov DA, Fortuna-Perez AP, Fortunato RH, Gagnon E, Gasson P, Rando JG, de Azevedo Tozzi AMG, Gunn B, Harris D, Haston E, Hawkins JA, Herendeen PS, Hughes CE, Iganci JRV, Javadi F, Kanu SA, Kazempour-Osaloo S, Kite GC, Klitgaard BB, Kochanovski FJ, Koenen EJM, Kovar L, Lavin M, le Roux M, Lewis GP, de Lima HC, López-Roberts MC, Mackinder B, Maia VH, Malécot V, Mansano VF, Marazzi B, Mattapha S, Miller JT, Mitsuyuki C, Moura T, Murphy DJ, Nageswara-Rao M, Nevado B, Neves D, Ojeda DI, Pennington RT, Prado DE, Prenner G, de Queiroz LP, Ramos G, Filardi FLR, Ribeiro PG, RicoArce ML, Sanderson MJ, Santos-Silva J, São-Mateus WMB, Silva MJS, Simon MF, Sinou C, Snak C, de Souza ÉR, Sprent J, Steele KP, Steier JE, Steeves R, Stirton CH, Tagane S, Torke BM, Toyama H, da Cruz DT, Vatanparast M, Wieringa JJ, Wink M, Wojciechowski MF, Yahara T, Yi T, Zimmerman E (2017) A new subfamily classification of the Leguminosae based on a taxonomically comprehensive phylogeny. Taxon 66(1), 44-77. doi:10.12705/661.3

Barneby RC (1991) Sensitivae Censitae: a description of the genus Mimosa Linnaeus (Mimosaceae) in the New World. Memoirs of the New York Botanical Garden 65, 1-835. 
Bentham G (1841) Notes on Mimoseae, with a short synopsis of species. Journal of Botany by William Hackson Hooker 4, 243-392.

Bentham G (1842) Notes on Mimoseae, with a short synopsis of species. Journal of Botany by William Hackson Hooker 4, 393-418.

Bentham G (1846) Notes on Mimoseae, with a short synopsis of species. London Journal of Botany 5, 75-108.

Bentham G (1875) Revision of the suborder Mimoseae. Transactions of the Linnean Society of London 30, 335-664. doi:10.1111/j.1096-3642.1875.tb00005.x

Bentham G (1876) Mimosa and Schranckia. In 'Flora Brasiliensis. Vol. 15 Pt. 2'. (Eds CPF Martius, AW Eichler, I Urban) pp. 294-391. (F. Fleischer: Munich and Leipzig, Germany)

Bernardello G, Sanderson GJ, López S, Cleland MA, Stuessy TF, Crawford DJ (1999) Reproductive biology of Lactoris fernandeziana (Lactoridaceae). American Journal of Botany 86(6), 829-840. doi: $10.2307 / 2656704$

Bessega C, Fortunato RH (2011) Section Mimadenia: its phylogenetic relationships within the genus Mimosa (Leguminosae, Mimosoideae) using plastid trnL-F sequence data. Australian Systematic Botany 24(2), 104-110. doi:10.1071/SB10022

Bir SS, Kumari S (1975) IOPB chromosome number reports XLIX. Taxon 24, 501-516.

Brochmann C, Brysting AK, Alsos IG, Borgen L, Grundt HH, Scheen A-C, Elven R (2004) Polyploidy in arctic plants. Biological Journal of the Linnean Society. Linnean Society of London 82, 521-536. doi:10.1111/j.1095-8312.2004.00337.x

Burkart A (1948) Las especies de Mimosa de la Flora Argentina. Darwiniana 8, 9-231.

Dahmer N, Simon MF, Schifino-Wittmann MT, Hughes CE, Miotto STS, Giuliani JC (2011) Chromosome numbers in the genus Mimosa L.: cytotaxonomic and evolutionary implications. Plant Systematics and Evolution 291, 211-220. doi:10.1007/s00606-010-0382-2

Di Rienzo JA, Casanoves F, Balzarini MG, González L, Tablada M, Robledo CW (2009) 'InfoStat versión 2009.' (Grupo InfoStat-Universidad Nacional de Córdoba: Córdoba, Argentina)

Egozcue J (1971) 'Técnicas en Citogenética.' (Espaxs: Barcelona, Spain)

Fortunato RH, Beyhaut R, Costa Bortoluzzi RL, Gómez Sosa EV, Izaguirre P, Lima HC, Miotto STS, Moura Baptista LR, Ulibarri EA (2008) Fabaceae. In 'Catálogo de Plantas Vasculares del Cono Sur. Vol. 2'. (Eds FO Zuloaga, O Morrone, MJ Belgrano) pp. 2078-2251. (Missouri Botanical Garden Press: Saint Louis, MO, USA)

Goldblatt P (1981) Cytology and the phylogeny of Leguminosae. In 'Advances in Legume Systematics, Vol. 2'. (Eds RM Polhill, PH Raven) pp. 427-464. (Royal Botanic Gardens, Kew: London, UK)

Grohar M, Rosenfeldt S, Morales M (2016) Leaflet trichome micromorphology in the Dolentes-Brevipedes taxonomic complex (Mimosa L., Mimosoideae). Turkish Journal of Botany 40, 45-58. doi:10.3906/bot-1412-40

Hammer Ø, Harper DAT, Ryan PD (2001) PAST: paleontological statistics software package for education and data analysis. Palaeontologia Electronica 4, 1-9.

Hans AS (1973) Chromosomal Conspectus of the Euphorbiaceae. Taxon 22 (5-6), 591-636. doi:10.2307/1218637

Isely D (1971) Legumes of the United States. IV. Mimosa. American Midland Naturalist 85(2), 410-424. doi:10.2307/2423765

Katsiotis A, Forsberg RA (1995) Production and cytogenetics of tetraploidoctoploid Avena hybrids. Plant Breeding 114(2), 137-143. doi:10.1111/j.1439-0523.1995.tb00778.x

Levene H (1960) Robust tests for equality of variances. In 'Contributions to Probability and Statistics: Essays in Honor of Harold Hotelling'. (Eds I Olkin, SG Ghurye, W Hoeffding, WG Madow, HB Mann) pp. 278-292. (Stanford University Press: Palo Alto, CA, USA)

Lewis GP, Schrire BD, Mackinder B, Lock M (2005) 'Legumes of the World.' (Royal Botanic Gardens Kew: London, UK)
Mahibbur Rahman M, Govindarajulu Z (1997) A modification of the test of Shapiro and Wilk for normality. Journal of Applied Statistics 24(2), 219-236. doi:10.1080/02664769723828

Majure LC, Judd WS, Soltis PS, Soltis DE (2012) Cytogeography of the Humifusa clade of Opuntia s.s. Mill. 1754 (Cactaceae, Opuntioideae, Opuntieae): correlations with pleistocene refugia and morphological traits in a polyploid complex. Comparative Cytogenetics 6(1), 53-77. doi:10.3897/compcytogen.v6i1.2523

Mann HB, Whitney DR (1947) On a test of whether one of two random variables is stochastically larger than the other. Annals of Mathematical Statistics 18(1), 50-60. doi:10.1214/aoms/1177730491

Morales M (2011) Relaciones entre especies del género Mimosa (Mimosoideae, Leguminosae) mediante estudios taxonómicos y citogenéticos. PhD thesis, University of Buenos Aires, Buenos Aires, Argentina.

Morales M, Fortunato RH (2016) A new xerophytic species of Mimosa (Leguminosae) from Madagascar. Phytotaxa 270(4), 277-285. doi:10.11646/phytotaxa.270.4.4

Morales M, Wulff AF, Fortunato RH, Poggio L (2010) Chromosome and morphological studies in the Mimosa debilis complex (Mimosoideae, Fabaceae) from southern South America. Australian Journal of Botany 58(1), 12-22. doi:10.1071/BT09132

Morales M, Wulff AF, Fortunato RH, Poggio L (2011) Karyotype studies in Mimosa (Mimosoideae, Leguminosae) from southern South America and ecological and taxonomic relationships. Caryologia 64(2), 203-214. doi:10.1080/00087114.2002.10589785

Morales M, Ribas OS, Santos-Silva J (2012) A new polyploid species of Mimosa (Leguminosae, Mimosoideae) from highlands of southern Brazil. Systematic Botany 37(2), 399-403. doi: $10.1600 / 036364412 X 635458$

Morales M, Wulff AF, Fortunato RH, Poggio L (2014a) Chromosome studies in southern species of Mimosa (Fabaceae, Mimosoideae) and their taxonomic and evolutionary inferences. Plant Systematics and Evolution 300, 803-817. doi:10.1007/s00606-013-0920-9

Morales M, Arenas L, Remis MI, Wulff AF, Poggio L, Fortunato RH (2014b) Morphometric and cytogenetic studies in Mimosa diversipila (Mimosoideae, Leguminosae) and their taxonomic and evolutionary inferences. Systematic Botany 39(3), 875-883. doi:10.1600/036364414X682166

Morales M, Wulff AF, Fortunato RH, Poggio L (2015) Primeros estudios cariotípicos en Mimosa farinosa y M. velloziana (Leguminosae, Mimosoideae). Bonplandia 24(1), 57-62.

Morales M, Giannoni F, Inza VM, Soldati C, Bessega C, Poggio L, Zelener N, Fortunato RH (2016) Estudios morfológicos, citogenéticos y moleculares en poblaciones de Mimosa subseries Dolentes y Brevipedes (Leguminosae, Mimosoideae). In 'Libro de Resúmenes de la II Reunión Argentina de Jóvenes Botánicos'. (Eds. Sociedad Argentina de Botánica) p. 52. (Sociedad Argentina de Botánica-IBONECONICET: Corrientes, Argentina)

Nazeer MA, Madhusoodanan KJ (1983) Intraspecific polyploidy in Mimosa pudica Linn. Current Science 52, 128-129.

Olkoski D, Schifino-Wittmann MT (2011) Cytogenetics of Mimosa bimucronata (DC.)O.Kuntze (Mimosoideae, Leguminosae): chromosome number, polysomaty and meiosis. Crop Breeding and Applied Biotechnology 11(1), 27-36. doi:10.1590/S1984-70332011000100004

Poggio L, Espert S, Fortunato RH (2008) Citogenética evolutiva en leguminosas americanas. Rodriguésia 59(3), 423-433.

Reeves A (2001) MicroMeasure: a new computer program for the collection and analysis of cytogenetic data. Genome 44, 439-443. doi: $10.1139 / \mathrm{g} 01-037$

Romero Zarco CR (1986) A new method for estimating karyotype asymmetry. Taxon 35, 526-530. doi: $10.2307 / 1221906$

Sanderson SC (2011) Natural polyploidization within tetraploid and hexaploid populations of the desert shrub Atriplex confertifolia. 
Western North American Naturalist 71(2), 141-150. doi:10.3398/064.071.0201

Santos-Silva J, Tozzi AMGA, Fragomeni M, Guedes Urquiza N, Morales M (2013) Evolution of trichome morphology in Mimosa L. (LeguminosaeMimosoideae). Phytotaxa 119, 1-20.

Scott AD, Stenz NW, Ingvarsson PK, Baum DA (2016) Whole genome duplication in coast redwood (Sequoia sempervirens) and its implications for explaining the rarity of polyploidy in conifers. New Phytologist 211(1), 186-193. doi:10.1111/nph.13930

Seijo GJ (1993) Citogenética en especies argentinas del género Mimosa (Leguminosae). Boletín de la Sociedad Argentina de Botánica 29, 219-223.

Seijo GJ (1999) Chromosome studies in Argentinian species of Mimosa. Cytologia 64, 241-246. doi:10.1508/cytologia.64.241

Seijo GJ (2000) Números cromosómicos en especies de Mimosa de Paraguay. Bonplandia 10, 163-167.
Seijo GJ, Fernández A (2001) Chromosome numbers of some southernmost species of Mimosa L. (Leguminosae). Cytologia 66, 19-23. doi:10.1508/cytologia.66.19

Simon MF, Grether R, Queiroz LP, Särkinen TE, Dutra VF, Hughes CE (2011) The evolutionary history of Mimosa (Leguminosae): toward a phylogeny of the sensitive plants. American Journal of Botany 98(7), 1201-1221. doi:10.3732/ajb.1000520

Stebbins GL (1971) 'Chromosomal Evolution in Higher Plants.' (Edward Arnold: London, UK)

Stebbins GL (1984) Polyploidy and the distribution of the arctic-alpine flora: new evidence and a new approach. Botanica Helvetica 94, 1-13.

Handling editor: Jeremy Bruhl

Appendix 1

Table A1. Shapiro-Wilk's test applied to quantitative variables analysed

\begin{tabular}{lcc}
\hline Character & $\mathrm{W}^{*}$ & $p$ (unilateral D) \\
\hline Petiole length & 0.77 & $<0.001$ \\
Pinna rachis length & 0.86 & $<0.001$ \\
Leaflet number of pairs per pinna & 0.91 & 0.02 \\
Leaflet length & 0.73 & $<0.001$ \\
Leaflet width & 0.67 & $<0.001$ \\
Leaflet ratio length : width & 0.90 & 0.0058 \\
Leaflet visible primary veins per leaflet & 0.90 & 0.0067 \\
Peduncle length & 0.77 & $<0.001$ \\
Legume cluster largest diameter & 0.88 & $<0.001$ \\
Legume cluster smallest diameter & 0.89 & 0.002 \\
Capitula or fruit clusters per inflorescence axis & 0.63 & $<0.001$ \\
Nodes per inflorescence axis & 0.84 & $<0.001$ \\
\hline
\end{tabular}

Table A2. Levene's test in Mimosa subseries Dolentes-Brevipedes complex comparing groups from cluster analysis

\begin{tabular}{lcc}
\hline Character & Levene's test & Levene's test for medians \\
\hline Petiole length (mm) & $<0.010$ & $<0.001$ \\
Rachis, length (mm) & 0.130 & 0.100 \\
Leaflet length (mm) & 0.010 & 0.030 \\
Leaflet width (mm) & $<0.010$ & 0.050 \\
Leaflet, ratio length:width & 0.05 & 0.441 \\
Peduncle length (mm) & 0.01 & 0.005 \\
Legume cluster largest diameter (mm) & 0.01 & 0.001 \\
Legume cluster smallest diameter (mm) & 0.002 & 0.008 \\
Number of leaflet pairs per pinna & 0.181 & 0.314 \\
Visible primary nerves per leaflet & 0.595 & 0.691 \\
Heads or fruit clusters per inflorescence axis & 0.001 & 0.01 \\
Nodes per inflorescence axis & 0.046 & 0.544 \\
\hline
\end{tabular}


Table A3. Non-parametric Mann-Whitney tests in quantitative characters in Mimosa subseries Dolentes-Brevipedes complex, comparing five groups detected by means unweighted pair-group method with arithmetic mean (UPGMA) cluster analysis

\begin{tabular}{|c|c|c|c|c|c|}
\hline Character & 4 & 1 & 5 & 3 & 2 \\
\hline \multicolumn{6}{|c|}{ Applied to petiole length } \\
\hline 4 & & 0.8446 & $0.0414 *$ & $0.0112 *$ & $0.0061 *$ \\
\hline 1 & 0.8446 & & $0.0365^{*}$ & $0.0294 *$ & $0.0062 *$ \\
\hline 5 & $0.0414^{*}$ & $0.0366^{*}$ & & $0.0058 *$ & $0.0019 *$ \\
\hline 3 & $0.0112 *$ & $0.0294 *$ & $0.0058 *$ & & 0.3742 \\
\hline 2 & $0.0061 *$ & $0.0062 *$ & $0.0019 *$ & 0.3742 & \\
\hline \multicolumn{6}{|c|}{ Applied to rachis of pinnae length } \\
\hline 4 & & $0.01083 *$ & 0.4967 & 0.0701 & 0.0552 \\
\hline 1 & $0.0108 *$ & & $0.0194 *$ & 0.0467 & 0.9516 \\
\hline 5 & 0.4967 & $0.0194 *$ & & 0.0058 & $0.0019 *$ \\
\hline 3 & 0.0701 & $0.0467 *$ & $0.0058 *$ & & $0.0035^{*}$ \\
\hline 2 & 0.0552 & 0.9516 & $0.0019 *$ & 0.0035 & \\
\hline \multicolumn{6}{|c|}{ Applied to leaflet pairs per pinna } \\
\hline 4 & & $0.0058 *$ & 0.1109 & 0.0564 & 0.1721 \\
\hline 1 & $0.0058^{*}$ & & 0.7086 & $0.0099 *$ & $0.0041 *$ \\
\hline 5 & 0.1109 & 0.7086 & & $0.0181^{*}$ & $0.0144 *$ \\
\hline 3 & 0.0564 & $0.0099 *$ & $0.0181^{*}$ & & $0.030^{*}$ \\
\hline 2 & 0.1721 & $0.0040 *$ & $0.0144 *$ & $0.030^{*}$ & \\
\hline \multicolumn{6}{|c|}{ Applied to leaflet length } \\
\hline 4 & & 0.2145 & $0.0414 *$ & 0.1128 & 0.0552 \\
\hline 1 & 0.2145 & & $0.0194 *$ & 0.6358 & $0.0043^{*}$ \\
\hline 5 & $0.0414 *$ & $0.01945^{*}$ & & $0.0094 *$ & $0.0019 *$ \\
\hline 3 & 0.1128 & 0.6358 & $0.0094 *$ & & $0.0099 *$ \\
\hline 2 & 0.0552 & $0.00432 *$ & $0.0019 *$ & $0.010^{*}$ & \\
\hline \multicolumn{6}{|c|}{ Applied to leaflet width } \\
\hline 4 & & 0.0581 & 0.3079 & $0.0462 *$ & $0.0717^{*}$ \\
\hline 1 & 0.0581 & & $0.0194 *$ & 0.9244 & $0.0043 *$ \\
\hline 5 & 0.3079 & $0.0194 *$ & & $0.0227^{*}$ & $0.0019 *$ \\
\hline 3 & $0.0462 *$ & 0.9244 & $0.0227 *$ & & $0.0099 *$ \\
\hline 2 & 0.0717 & $0.0043 *$ & $0.0019 *$ & $0.0099 *$ & \\
\hline \multicolumn{6}{|c|}{ Applied to leaflet primary nerves } \\
\hline 4 & & $0.0225^{*}$ & 0.0521 & $0.0008^{*}$ & $0.0006^{*}$ \\
\hline 1 & $0.0225 *$ & & 0.6056 & 0.1092 & 0.6357 \\
\hline 5 & 0.0521 & 0.6056 & & $0.0228 *$ & 0.2397 \\
\hline 3 & $0.0008 *$ & 0.1092 & $0.0228 *$ & & $0.0424 *$ \\
\hline 2 & $0.000^{*}$ & 0.6357 & 0.2397 & $0.0424 *$ & \\
\hline \multicolumn{6}{|c|}{ Applied to peduncle length } \\
\hline 4 & & 0.4723 & 0.6504 & 0.6507 & $0.0021 *$ \\
\hline 1 & 0.4723 & & 0.9021 & 0.7763 & $0.0179 *$ \\
\hline 5 & 0.6504 & 0.9021 & & 1.0000 & $0.0113 *$ \\
\hline 3 & 0.6507 & 0.7763 & 1.0000 & & $0.0077^{*}$ \\
\hline 2 & $0.0021 *$ & $0.0179 *$ & $0.0113^{*}$ & $0.0077^{*}$ & \\
\hline \multicolumn{6}{|c|}{ Applied to pod cluster major diameter } \\
\hline 4 & & $0.0074 *$ & 0.1923 & 0.0853 & $0.0001 *$ \\
\hline 1 & $0.0074 *$ & & $0.0194 *$ & $0.0467 *$ & 0.9032 \\
\hline 5 & 0.1923 & $0.0194 *$ & & 0.6261 & $0.0018 *$ \\
\hline 3 & 0.0853 & $0.0467 *$ & 0.6261 & & $0.0035^{*}$ \\
\hline 2 & $0.0001 *$ & 0.9032 & $0.0018 *$ & $0.0035^{*}$ & \\
\hline \multicolumn{6}{|c|}{ Applied to minor pod cluster diameter } \\
\hline 4 & & $0.00496 *$ & 0.2815 & 0.2048 & 0.08118 \\
\hline 1 & $0.0050^{*}$ & & $0.0194 *$ & $0.0179 *$ & 0.6261 \\
\hline 5 & 0.2815 & $0.0194 *$ & & 1.0000 & $0.0019 *$ \\
\hline 3 & 0.2048 & $0.0179 *$ & 1.0000 & & $0.0015^{*}$ \\
\hline 2 & 0.0812 & 0.6261 & $0.0019 *$ & $0.0015^{*}$ & \\
\hline \multicolumn{6}{|c|}{ Applied to capitula per inflorescence } \\
\hline 4 & & $0.0037 *$ & $0.0017 *$ & 0.0957 & $0.0083 *$ \\
\hline 1 & $0.0037 *$ & & 0.7972 & $0.0073^{*}$ & 0.1996 \\
\hline 5 & $0.0016^{*}$ & 0.7972 & & $0.0041 *$ & 0.1114 \\
\hline 3 & 0.0957 & $0.0073 *$ & $0.0041 *$ & & 0.1456 \\
\hline 2 & $0.0083 *$ & 0.1996 & 0.1114 & 0.1456 & \\
\hline
\end{tabular}


Table A4. Levene's test in Mimosa subseries Dolentes-Brevipedes complex comparing ploidy levels

\begin{tabular}{lcc}
\hline Character & Levene's test & Levene's test for medians \\
\hline Petiole length (mm) & 0.3160 & 0.8600 \\
Rachis, length (mm) & 0.1300 & 0.1000 \\
Leaflet length (mm) & 0.0838 & 0.4520 \\
Leaflet width (mm) & 0.0819 & 0.4595 \\
Leaflet, ratio length:width & 0.1576 & 0.1902 \\
Peduncle length (mm) & 0.0143 & 0.0448 \\
Legume cluster largest diameter (mm) & 0.0029 & 0.0036 \\
Legume cluster smallest diameter (mm) & 0.0122 & 0.0094 \\
Number of leaflet pairs per pinna & 0.1392 & 0.3229 \\
Visible primary nerves per leaflet & $<0.0010$ & 0.0200 \\
Head or fruit clusters per inflorescence axis & 0.4924 & 0.3757 \\
Nodes per inflorescence axis & 0.0261 & 0.0395 \\
\hline
\end{tabular}

